\title{
Hanford Site Protective Barrier Development Program: Fiscal Year 1990 Highlights
}

September 1991

Prepared for the U.S. Department of Energy under Contract DE-AC06-76RLO 1830

Pacific Northwest Laboratory Operated for the U.S. Department of Energy by Battelle Memorial Institute 


\title{
DISCLAIMER
}

This report was prepared as an account of work sponsored by an agency of the United States Government. Neither the United States Government nor any agency thereof, nor Battelle Memorial Institute, nor any of their employees, makes any warranty, expressed or implied, or assumes any legal liability or responsibility for the accuracy, completeness, or usefulness of any information, apparatus, product, or process disclosed, or represents that its use would not infringe privately owned rights. Reference herein to any specific commercial product, process, or service by trade name, trademark, manufacturer, or otherwise does not necessarily constitute or imply its endorsement, recommendation, or favoring by the United States Government or any agency thercof, or Battelle Memorial Institute. The views and opinions of authors expressed herein do not necessarily state or reflect those of the United States Government or any agency thereof.

\author{
PACIFIC NORTHWEST LABORATORY \\ operated by \\ BATTELLE MEMORIAL INSTITUTE \\ for the \\ UNITED STATES DEPARTMENT OF ENERGY \\ under Contract DE-AC06-76RLO 1830
}

Printed in the United States of America

Available to DOE and DOE contractors from the

Office of Scientific and Technical Information, P.O. Box 62, Oak Ridge, TN 37831; prices available from (615) 576-8401. FTS 626-8401.

Available to the public from the National Technical Information Service, U.S. Department of Commerce, 5285 Port Royal Rd., Springfield, VA 22161. 
PNL --7831

DE92 001792

HANFORD SITE PROTECTIVE BARRIER

DEVELOPMENT PROGRAM: FISCAL YEAR

1990 HIGHLIGHTS

L. L. Cadwell, Editor

September 1991

Prepared for the

U.S. Department of Energy

under Contract DE-ACO6-76RLO 1830

Pacific Northwest Laboratory

Richland, Washington 99352 


\section{SUMMARY}

The Hanford Site Protective Barrier Development Program was jointly developed by Pacific Northwest Laboratory (PNL) and Westinghouse Hanford Company (WHC) to design and test an earthen cover system(s) that can be used to inhibit water infiltration; plant, animal, and human intrusion; and wind and water erosion. The joint PNLWHC program was initiated in FY 1986.

To date, research findings support the initial concepts of barrier designs for the Hanford Site. A fine-soil surface is planned to partition surface water into runoff and temporary storage. Transpiration by vegetation that grows in the fine-soil layer will return stored water to the atmosphere as will surface evaporation. A capillary break created by the interface of the fine-soil layer and coarser textured materials below will further limit the downward migration of surface water, making it available over a longer period of time for cycling to the atmosphere. Should water pass the interface, it will drain laterally through a coarse textured sand/gravel layer. Tested barrier designs appear to work adequately to prevent drainage under current and postulated wetter-climate (added precipitation) conditions. Wind and water erosion tasks are developing data to predict the extent of erosion on barrier surfaces. Data collected during the last year confirm the effectiveness of small burrowing animals in removing surface water. Water infiltrating through burrows of larger mammals was subsequently lost by natural processes. Natural analog and climate change studies are under way to provide credibility for modeling the performance of barrier designs over a long period of time and under shifts in climate. 


\section{CONTENTS}

SUMMARY

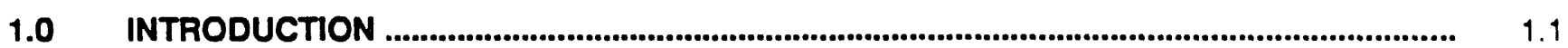

Functional Performance of Protective Barriers .................................................. 1.1

Hanford Site Protective Barrier Development Team................................................. 1.1

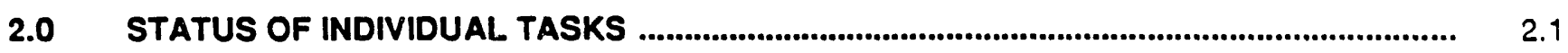

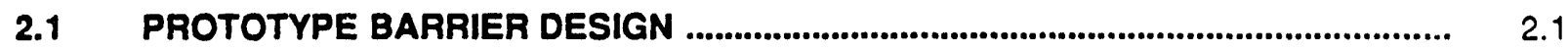

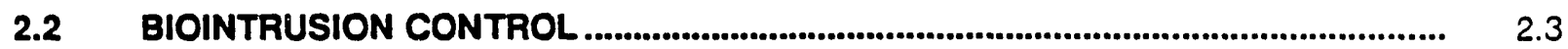

Animal Intrusion Studies: Small Mammals ........................................................ 2.3

Animal Intrusion Studies: Large Mammals ........................................................ 2.4

Root Intrusion Studies: Design and Initial Samples ................................................ 2.5

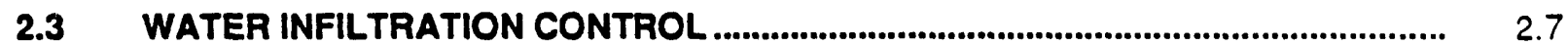

Field Lysimeter Test Facility ........................................................................... $\quad 2.7$

Plant Transpiration/Evapotranspiration .......................................................... 2.7

Diversion Barrier Testing ................................................................................ 2.9

2.4 EROSION/DEPOSITION CONTROL ........................................................................ 2.12

Field Study of Gravel Admix, Vegetation, and Soil ............................................... 2.12

Small Tube Lysimeter Tests ............................................................................... $\quad 2.12$

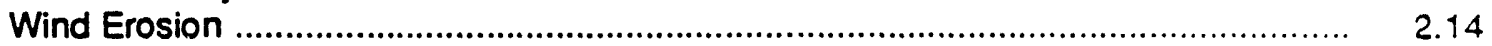

Water Erosion ............................................................................................... 2.16

2.5 MODEL APPLICATIONS AND VALIDATION ..................................................... 2.18

Model Applications and Validation ......................................................................... 2.18

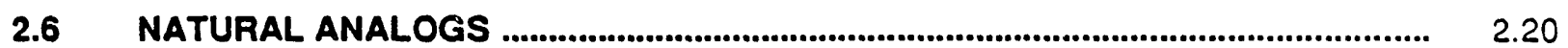

Pedogenic Carbonate Studies ............................................................................ $\quad 2.20$

Layer Interface Integrity ...................................................................................... $\quad 2.20$

Hummock/Swale Topographic Effects on Soil Water Patterns ................................. 2.20

2.7 LONG-TERM CLIMATE CHANGE EFFECTS ....................................................... 2.23

Long-Term Climate Effects ................................................................................. 2.23

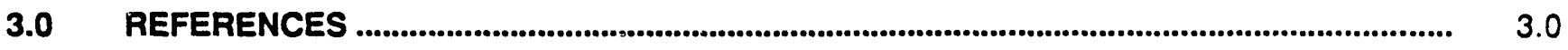

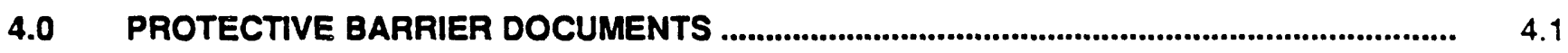

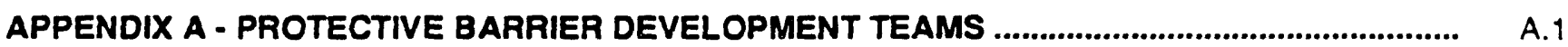




\section{FIGURES}

1.1 Typical Protective Barrier and Waming Marker System ........................................................ 1.2

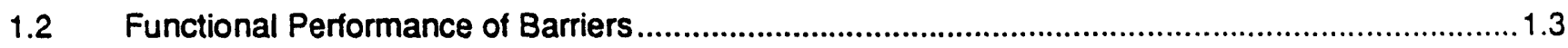

1.3 Barrier and Marker System Development Task Groups ...................................................... 1.3

2.1 Location of the Proposed Barrier Construction Site ................................................................2.2

2.2 Configuration of the Lysimeters at the Animal Intrusion Lysimeter Facility ...............................2.4

2.3 Mean Seasonal Change in Soil Moisture Around Badger Burrows at the

2.4 Root Distribution in Hummock Area McGee Ranch Hopsage Cover .........................................2.6

2.5 Root Distribution in Interhummock Area McGee Ranch Sagebrush Cover ................................2.6

2.6 Root Distribution in Interhummock Area McGee Ranch Grass Cover ....................................2.6

2.7 Lysimeter Drainage Linked to Temperature, Except for Sand Without a

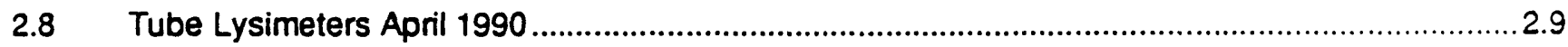

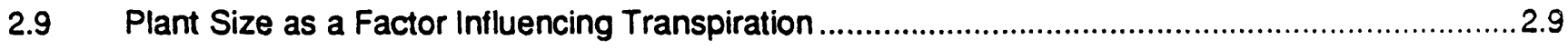

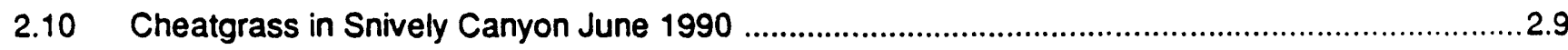

2.11 Water Balance for the Asphalt and Control Lysimeters During July 1988-

2.12 Water Balance for Asphalt and Control Lysimeters During November 1989-July

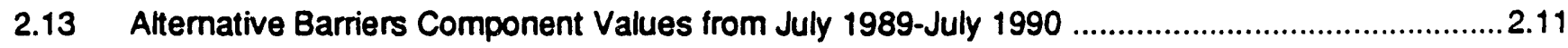

2.14 Vegetation Cover for Soil and 30\% Admix Treatment Plots for 1987, 1988, and 1989

2.15 Soil Moisture Storage Change Within the Top, Bottom, and

Total Profiles for Vegetated and Bare Surfaces with Natural and

Twice Average Precipitation Treatments for 0,15 , and 30 Percent Gravel

in the Surface Soil

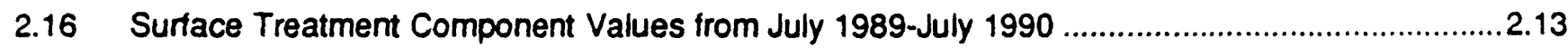

2.17 Bimodal Versus Graded Layering Component Values from July $1989-J u l y ~ 1990 \ldots \ldots \ldots \ldots \ldots \ldots \ldots \ldots . . . .14$

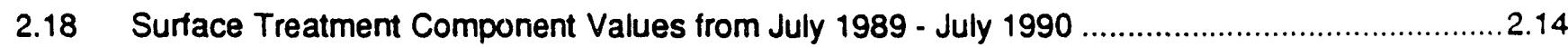




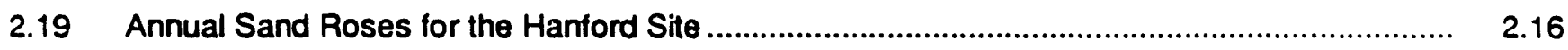

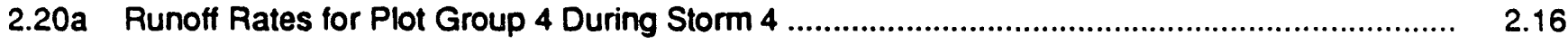

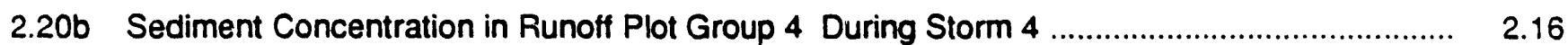

2.21 Estimated Flux Past the Bottom-Left Corner of the Waste Zone

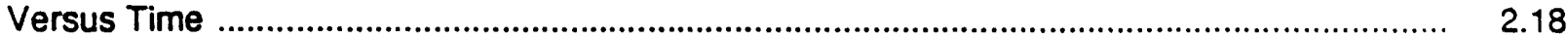

2.22 Comparison of Drainage Predicted by TOUGH and Measured from Asphalt

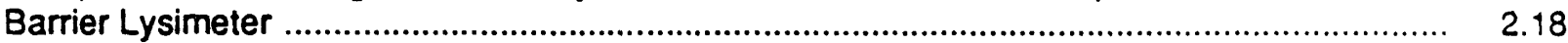

2.23 Contour Map of the Study Area Showing Hummocks, Swales, and Cover Classification

2.24 Soil Water Storage Dynamics in Bare Swales, Irrigated Bare Swales, Imigated Swales, Spiny Hopsage Hummocks, Imrigated Spiny Hopsage Hummocks, and Sagebrush Swales

2.25 Volumetric Soil Water Content Patterns with Depth on Day 88, 1990

2.26 Volumetric Soil Water Content Patterns with Depth on Day 215, 1990

2.27 Modern Distribution of Vegetation Zones in the Columbia Basin Compared with Reconstructions of Vegetation Patterns for Three Periods During the Holocene 


\subsection{INTRODUCTION}

Protective barrier and warning marker systems are being developed to isolate wastes disposed of near the Earth's surface at the Hanford Site in southeastern Washington. The protective barrier and warning marker systems use engineered layers of natural materials to create an integrated structure with redundant protective features. The natural construction materlals (e.g., fine soil, sand, gravel, riprap, clay, and asphalt) have been selected to optimize barrier performance and longevity. The objective of current designs is to use natural materlals to develop a protectlve barrier and warning marker system that isolates wastes for up to 10,000 years by limiting water drainage; reducing the likelihood of plant, animal, and human intrusion; controlling the exhalation of noxious gases; and minimizing erosionrelated problems.

\section{FUNCTIONAL PERFORMANCE OF PROTECTIVE BARRIERS}

Protective barriers consist of a variety of materials placed in layers to form an above-grade mound directly over awaste zone. A typical protective barrier, illustrated in Figure 1.1 consists of (from top to bottom) a fine-soil layer, a sand/fine-gravel layer, and a layer of coarse materials such as pitrun gravels or crushed basalt riprap. A layer of crushed basalt riprap also may be used on the shoulder, side slopes, and toe of the structure. Each layer serves a distinct purpose (Figure 1.2).

The fine-soil layer acts as a medium in which moisture can be stored until the processes of evaporation and transpiration can recycle excess water back to the atmosphere. The fine-soil layer also provides the medium for establishing plants, which are necessary fortranspiration to take place. Gravels may be admixed into or spread onto the surface of the fine soil layer to minimize wind and water erosion. The surface of the fine soil layer also may be engineered with a slight slope or crown to maximize runoff while minimizing erosion.

The sand/fine-gravel layer serves a dual purpose. First, the textural difference at the interface between the sand/fine-gravel layer and the fine-soil layer creates a capillary break. This capillary break inhibits the downward movement of moisture from the overlying unsaturated fine-soil layer past the interface. Second, the sand/fine-gravel layer acts as a fitter layer to prevent fine soils from penetrating into the void spaces of the coarser materials below.

Layers of low-permeability materials are being tested as redundant infiltration barriers. Should the fine soil layer fail to capture and recycle precipitation back to the atmosphere, a low-permeability layer (or layers) would direct water away from the wastes. The lowpermeability layer(s) would also function to check the upward movement of noxious gases from the waste zone.

Coarse materials such as pitrun gravels and crushed basalt riprap are used in the protective barrier as a deterrent for burrowing animals, deep-rooting plants. and human intruders. Crushed basalt riprap also may be used to provide wind and water erosion protection of the barrier shoulder, side slope, and toe.

Surface markers will be placed around the periphery of the waste sites to inform future generations of the nature and hazards of the buried wastes. In addition, throughout the protective barrier, subsurface markers will be placed to warn any inadvertent human intruders of the dangers of the buried wastes.

Because of the need for the barrier to perform for thousands of years without maintenance, natural construction materials (e.g., fine soil, sand, gravel, cobble, crushed basalt riprap, clay, and asphalt) have been selected to optimize barrier performance and longevity. These natural construction materials, most of which exist in large quantities on the Hanford Site. are known to have existed for thousands of years. Human made construction materials cannot be relied on at this point, because it is not currently known if they could survive and function properly for thousands of years.

\section{HANFORD SITE PROTECTIVE BARRIER DEVELOPMENT TEAM}

Before implementing protective barrier and warning marker systems for the final disposal of wastes at the Hanford Site, much development and evaluation 

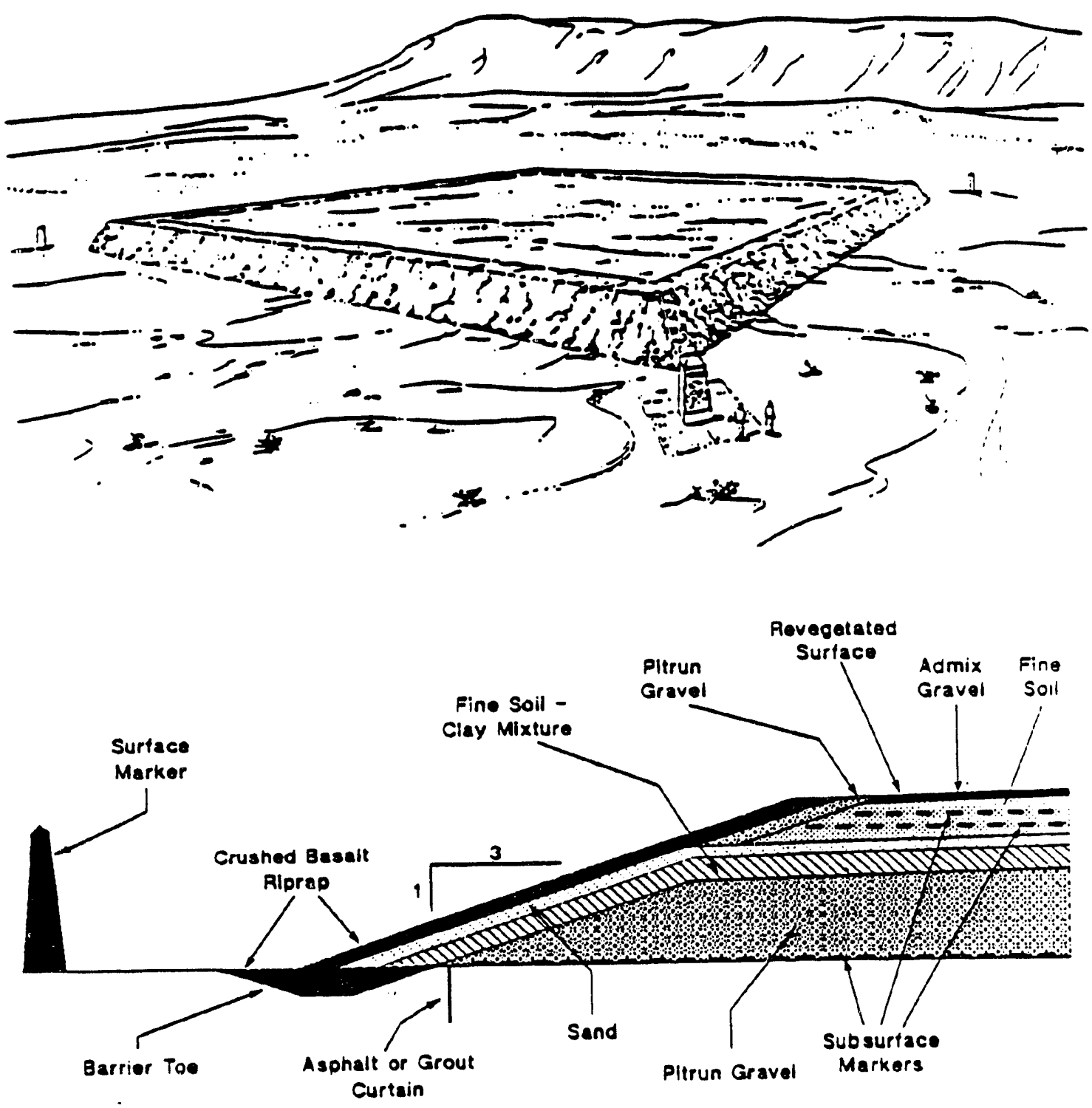

59001043

Figure 1.1. Typical Protective Barrier and Warning Marker System

work must be conducted to assess barrier and marker system performance. To accomplish this, engineers and scientists from Pacific Northwest Laboratory (PNL) and Westinghouse Hanford Company (WHC) formed the Hanford Site Protective Barrier Development Team in FY 1986. The team is responsible for planning and directing the performance of barrier and marker system development activities.

The Protective Barrier and Warning Marker System Development Plan (Adams and Wing 1986) organizes and coordinates activities associated with the development and testing of protective barrier and warning marker systems. Eleven technical task groups and a project management task have been identified to resolve the technical concerns and complete the development and design of protective barrier and warning marker systems (Figure 1.3).

The task groups are listed below.

- Project management

- Biointrusion control

- Water infiltration control

- Erosion/deposition control 


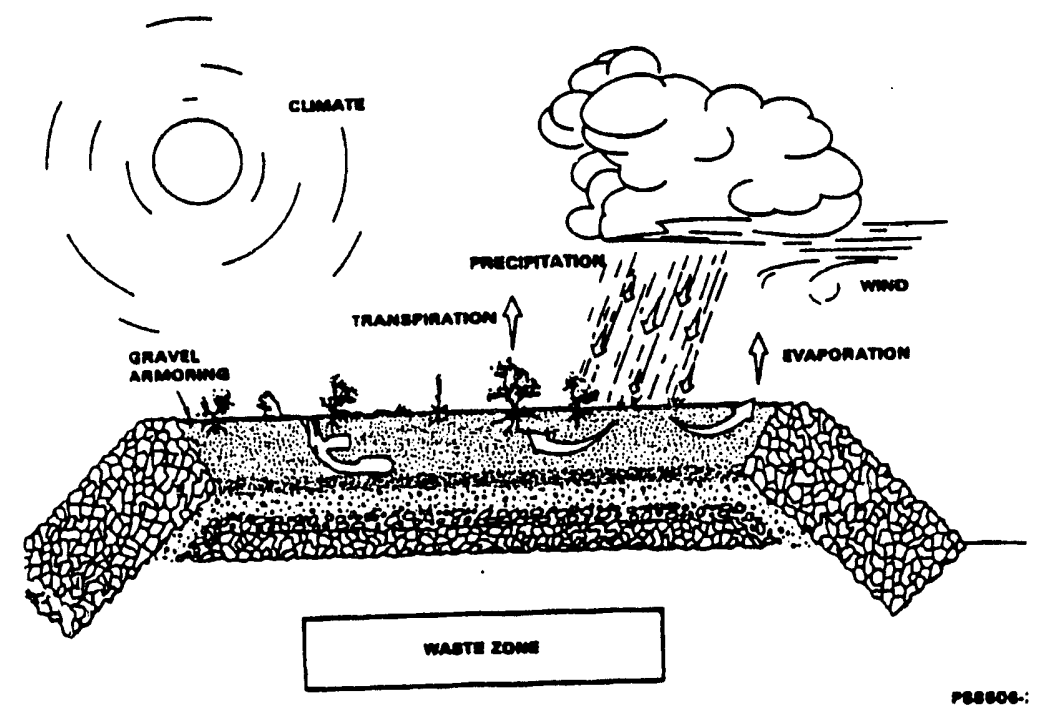

Figure 1.2. Functional Performance of Barriers

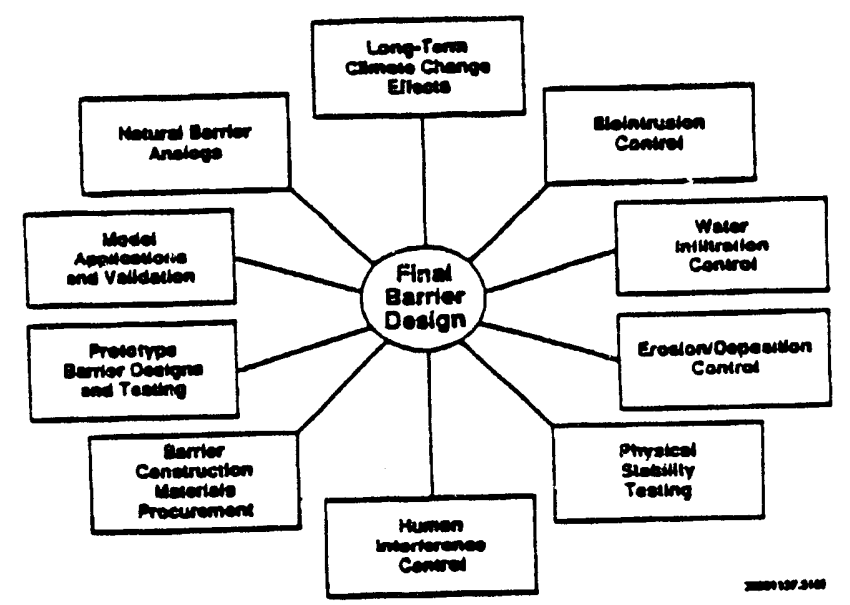

Figure 1.3. Barrier and Marker System Development Task Groups

- Physical stability testing

- Human interference control

- Barrier construction materials procurement

- Prototype barrier design and testing

- Model applications and validation

- Natural analog study

- Long-term climate change effects

- Final design.

Specific test plans and other detailed documents have been or are being prepared to plan, schedule, execute, and report on each of the technology development activities within these task groups. The results of activities performed are being used to develop detailed, final barrier and marker system designs.

Section 2.0 of this document summarizes the tasks and activities, identified above that were conducted during FY 1990. 


\subsection{STATUS OF INDIVIDUAL TASKS}

\subsection{PROTOTYPE BARRIER DESIGN}

Designing protective barriers is an evolving process. Each year, as tasks are performed, new data and information are collected, valuable experience is acquired, and insights into the approaches for solving barrier design problems are gained. As the Barrier Development Program progresses, conceptual barrier designs are frequently revised and modifled.

Periodically during the life of the Hanford Site Protectlve Barrier Development Program, full-scale prototypes of the latest barrier designs are planned for construction and fleld testing. This approach enables engineers and scientists to momentarlly freeze the barrier design(s) and obtain fleld experience in constructing protectlve barriers. Constructibility issues that are not readlly apparent on the original engineering drawings may be more easily detectable in the fleld. Another valuable. benefit of constructing prototypes in the fleld is that they allow all the components of the barrier to be brought together into an integrated system. This is particularly important because several barrier components are being developed independently.

\section{PROTOTYPE BARRIER DESIGN N. R. Wing (WHC)}

The design of a prototype barrier was initiated during FY 1990. A barrier design team (BDT) has been assembled to design the prototype barrier. The BDT (see Appendix A) includes representatives from WHC, PNL, and Kaiser Engineers Hanford (KEH), the architect/engineer for the Hanford Site. The BDT has met frequently with and received technical support from the barrier technical advisory board (BTAB) - a group of engineers and scientists on the barrier development team who represent various areas of technical expertise in the Barrier Development Program. Review comments and design suggestions from other barrier development team members also have been solicited and incorporated when appropriate.

The KEH has been responsible for transforming conceptual ideas from the BDT/BTAB into definitive, detailed construction drawings. The drawings have been subjected to numerous technical reviews and represent the optimal design for meeting the objectives of the prototype barrier project. These drawings will be cleared for public release when they are completed.

\section{Siting the Prototype Barrler}

The prototype barrier is planned to be constructed on the 200 Area Plateau between the 200 East and 200 West Areas and just northeast of the Hanford Meteorological Station (HMS) (Figure 2.1). The prototype's proximity to the HMS enables the meteorological information collected at the HMS to be used in assessing the prototype's performance.

The location of the site selected for constructing the prototype barrier is ideal for obtaining accurate estimates of the costs associated with constructing protective barriers. Barrier construction costs are very sensitive to and comprised largely of the costs associared with hauling construction materials. Most potential protective barriers sites that are being considered for waste remediation activities at Hanford are in the 200 Areas. Because the prototype barrier will be constructed at a site located between the 200 East and the 200 West Areas, representative and supportable costs for constructing barriers on the 200 Area Plateau can be estimated.

Some of the required documentation for constructing the prototype barrier has already been completed. For example, cultural resource reviews and biotic surveys have been conducted. The applicable documentation was prepared not only for the construction site selected, but for the borrow pits from which construction materials will be obtained.

\section{Prototype Barrier Testing}

Once the barrier is constructed, a number of tests and experiments are planned for it. These tests and experiments will assess the prototype's performance vis a vis water infiltration control, erosion control, biointrusion control, and physical stability. The tests and experiments will use instruments, transducers, 


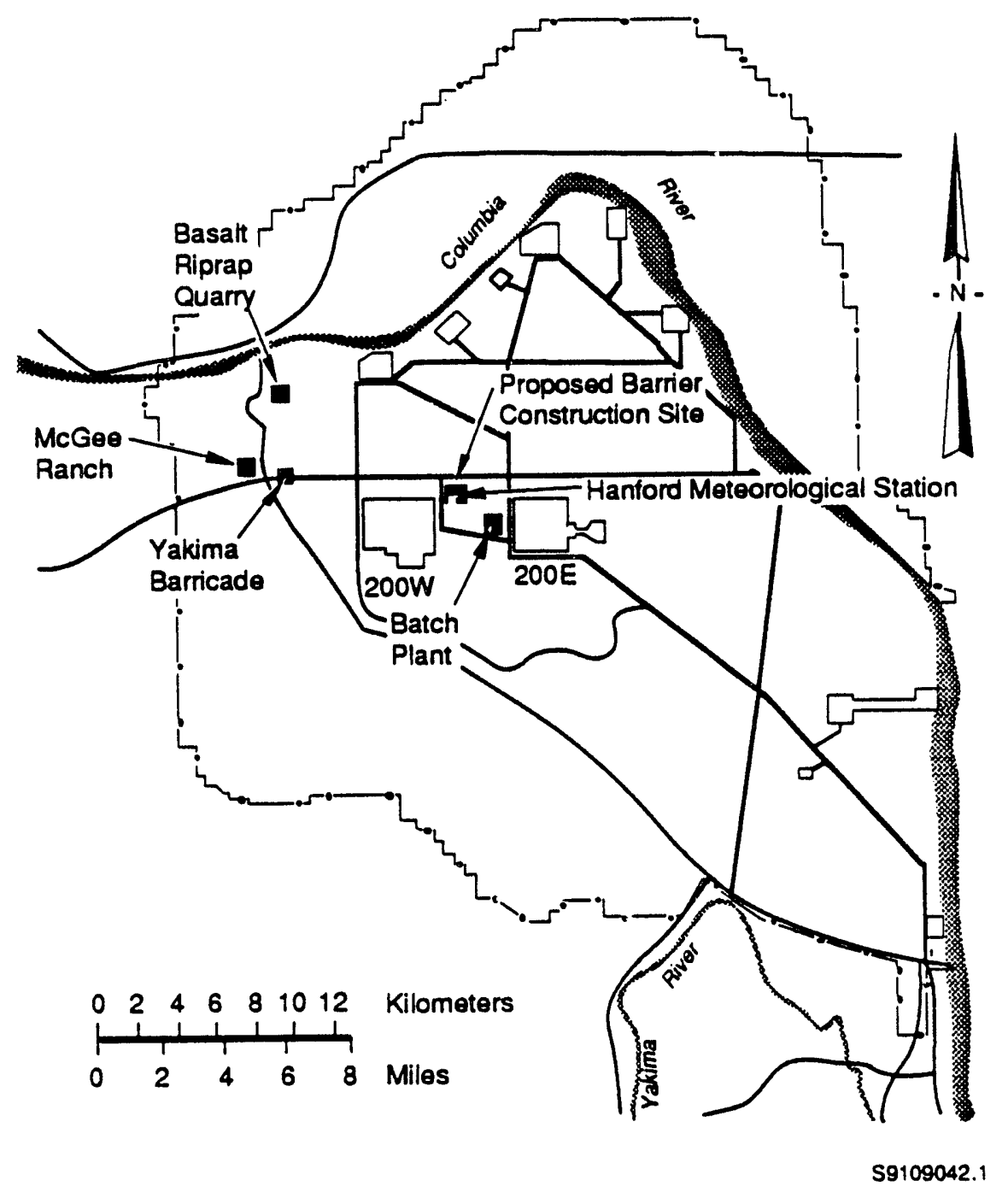

Figure 2.1. Location of the Proposed Barrier Construction Site

and nonradioactive/nonhazardous tracers placed throughout and around the prototype barrier.

It should be emphasized that constructing the prototype is a test. Constructibility issues raised during the construction of the prototype will be learned from and incorporated into future barrier designs.

\section{Status}

The majority of the design effort for the first large-scale prototype barrier for the Hanford Site was performed during FY 1990. Detailed conceptual designs, a comprehensive outline construction specification, and a letter repon documenting the design bases and engineering calculations for the prototype barrier were completed during the year. Future efforts will focus on ccmpleting definitive design drawings, preparing detailed construction specifications, and constructing the prototype barrier. An "enhanced" prototype barier may be designed and constructed in the future. This enhanced prototype would build on lessons learned from the design and construction of the first prototype. 


\subsection{BIOINTRUSION CONTROL}

Protectlve barriers with vegetated earthen covers will be Inhabited by many animal species over their 10,000-year design life. It is possible that animals ranging in size from anis to badgers and coyotes will burrow into the barrier surface. Burrowing animals may impact barriers by ' 1 ) constructing burrows that act as conduits for water penetration through the upper layer of the barrier, which could erode the sloped barrier shculder or permit water to enter the waste zone; 2) moving loose sull to the barrier surface where it is available for accelerated wind or water erosion; and 3) directly transporting contaminants to the surface with excavated soil.

The two biointrusion control tasks conducted during FY 1990 Involved experiments that assess the impacts of animal burrows on water Infittration. One experiment focused on burrows created by small mammals and one on burrows created by large mammals.

The objcetlve of the animal intr. ist in studles was to provide information for evaluating and predicting potenilal impacts of animal burruwing on barrler performance. They assess the impacts under current climatic conditions as well as under conditions simulating a wetter climate. Wetter climatic conditions may resuit in changes in species composition and thus increases in biomass.

\section{ANIMAL INTRUSION STUDIES: SMALL MAMMALS D. S. Landeen and C. J. Kemp (WHC)}

Introduction

An Animal Intrusion Lysimeter Facility was constructed in FY 1988 to assess the effects of small-mammal burrows on the infiltration of meteoric water through protective barriers. The facility, located next to the HMS, consists of two steel outer boxes with plywood sides buried in the ground so that the top of each box is flush with the original grade. These outer boxes serve as receptacles for six animal intrusion lysimeters: three lysimeters are housed in each outer box (Figure 2.2). Each lysimeter has been structurally engineered so that it can te ined out of the outer box with a crane. The side walls of the lysimeters also have been designed so they can be disassembled.

The animal intrusion lysimeters were designed so that a series of 3-to 4-month-long tests could be conducted at the facility. The following paragraphs describe how the lysimeter study is being used to assess the effects of animal burrowing on the infiltration of water through a protective barrier.

Each lysimeter is lined with a 28-mil pond liner and then filled with soil excavated from McGee Ranch, the borrow pit site for soils used to construct protective barriers. After the lysimeters are filled with soil, two hydroprobe ports are installed in each lysimeter. Soil moisture samples are collected at 6 -in. intervals at this time and also at the end of each test. Throughout the test period, soil moisture is measured with a neutron moisture probe.

One small burrowing mammal is introduced into each of four lysimeters, the other two serve as controls. The small mammals used in this study were the Great Basin pocket mouse, Perognatus parvus, the northern pocket gopher, Thomomys talpoides, and Townsend's ground squirrel, Spermophilus townsendii. Two species of animals were used per test. Animals were allowed to burrow for 3 to 4 months. During each test, supplemental precipitation was added to three of the six lysimeters using a rainfall simulator (rainulator). The supplemental precipitation was applied once a month at a rate equivalent to a 100-year storm event at the Hanford Site ( $0.55 \mathrm{in}$. of water in $13 \mathrm{~min}$ ).

\section{Results}

To date, four sets of tests have been completed. Preliminary results from the first test using pocket mice and ground squirrels, conducted during the summer of 1988, indicate that water added with the rainulator to two lysimeters with burrowing animals was being removed. The water in the soils of the lysimeters (even those lysimeters receiving supplemental precipitation) was not being stored, but was evaporating. Over 3 to 4 months, the data did not indicate a significant difference in the water contents of the soils at depth in the lysimeters with animal burrows, compared with the water content of soils at depth in the control lysimeters, 


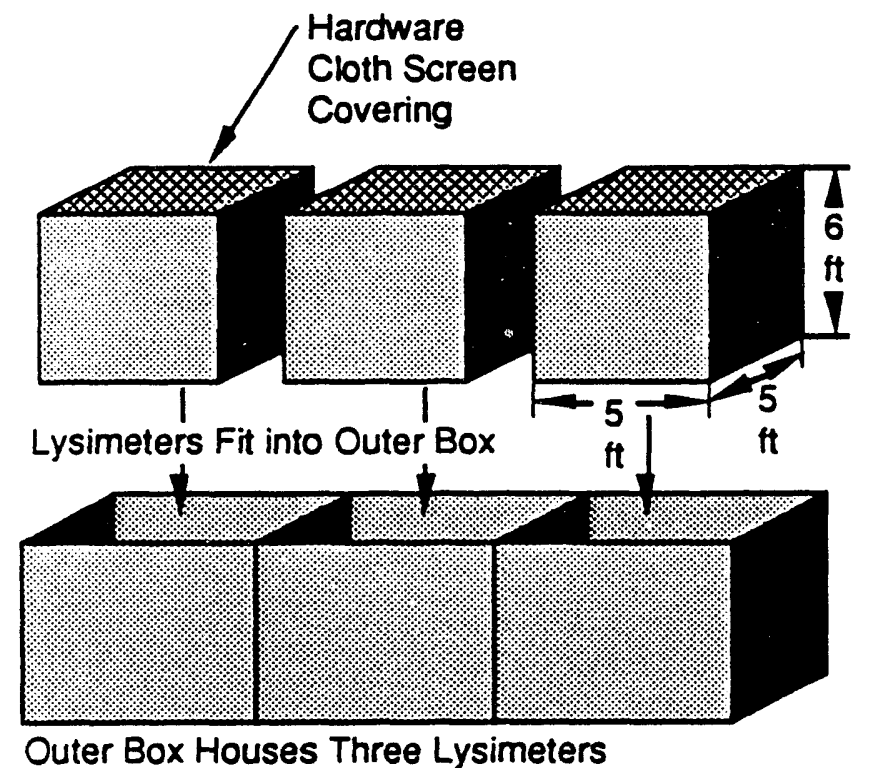

S9109042.12

Figure 2.2. Configuration of Lysimeters at the Animal Intrusion Lysimeter Facility

which did not have animal burrows.

Data from the second test using pocket gophers and pocket mice, which was conducted during winter 1988/ 1989 indicated that all the lysimeters (controls and animals) gained water. Lysimeters with animal burrows gained almost twice as much water as the control lysimeters. The greatest changes were observed at the 18-in.-depth level in all lysimeters.

Results of test three (summer treatment 1989), which used ground squirrels and pocket gophers, indicated that the additional 1.5 in. of precipitation that was added with the rainulator was lost during this test. The lysimeters that did not receive any additional precipitation all lost water. The hydroprobe readings also confirmed this overall trend of water loss throughout the test period.

Test four was a winter treatment (1989/1990) using pocket gophers and pocket mice. Results showed that all lysimeters except one (animal with no supplemental precipitation) gained water. The hydroprobe data also confirmed the trend of increasing soil moisture conditions. The two control lysimeters (no animals) gained the most water. This was a different result than shown in test two, also conducted in winter, which indicated that the control lysimeters showed the least amount of gain in soil moisture. The difference can probably be explained by the degree of burrowing activity, which for some reason was significantly higher during test two.

\section{Summary}

Information collected from the first four tests indicate the following trends: 1) during summer months, water is lost in all lysimeters, including the additional precipitation added with the rainulator; 2 ) during winter months, lysimeters (animals and controls) gain water; and 3) no significant water infiltration has occurred below 36 in. even though burrow depths always exceed 48 in.

The lack of any significant water infiltration at depth and the overall water loss in the lysimeters occurs despite the following worst case conditions that have been imposed on the lysimeters: 1) no vegetative cover (no evapotranspiration), 2) no water runoff (all water contained), 3) higher than normal animal and burrow densities, 4) supplemental precipitation added at rates not normally expected to occur, and 5) animals usually burrow to the bottom of the lysimeters.

Preliminary conclusions from the data indicate that little difference exists between control and animal lysimeters in the amount of waier stored. This would indicate that small mammal burrowing does not affect soil moisture content. If this is the case, then the overall water loss must be attributed to processes that occur equally in control and treatment lysimeters (surface evaporation). It appears that other variables such as soil turnover from burrowing activities and burrow ventilation effects, which help remove moisture, may be influential, but, in the final analysis, make no difference as far as water content at the end points (times) used in this study.

\section{ANIMALINTRUSION STUDIES: LARGE MAMMALS L. L. Cadwell, L. E. Eberhardt, M. A. Simmons, P. B. Test, V. Parks, and M. J. Harris (PNL)}

Burrowing animals ranging in size from small invertebrates such as ants to medium-size mammals, including badgers, coyotes, and marmots may impact protective barrier effectiveness in three important ways. First, ourrows may provide a preferred path for surface water to enter the upper layers of the barrier, thus reducing the effectiveness of the barrier in limiting infiltration. Second, burrowing animals, by casting excavated soil to the barrier surface, may contribute to increased erosion of the fine-soil cover and thereby decrease barrier longevity. Finally, burrowing animals 
have the potential to dig through soil covers, contact buried wastes, and move contaminants to the surface.

Observations made with simulated rainiall in previous years showed that large burrows dug by coyotes and badgers can divert surface water deep into barrier soils. Measurements made in FY 1989 and FY 1990 document that under natural rainfall, precipitation penetrates deep beneath and around badger burrows. However, the water is subsequently withdrawn (Figure 2.3). In disturbed soils near burrows, the vigorous growth of invading plant species may result in the preferential extraction of water through plant transpiration. Enhanced evaporation from the soil surfaces exposed by burrowing may also preferentially remove soil water near burrows. Our data showed that the soil beneath burrows in mid-summer was actually drier than in adjacent areas away from burrows. Vegetation sampling showed that plant densities (mustards) were significantly greater in the vicinity of badger burrows after the 1989 growing season than in nearby locations away from burrows. Studies are currently under way to determine whether the preferential drying occurs in soils beneath the burrows in the absence of vegetation.

Studies also were conducted to quantify the amount of runoff entering badger burrows. A nunoff generator was used to apply water along the slope above badger burrows. Results from these studies showed that burrows intercept a considerably greater amount of runoff than expected based solely on the surface area of the burrow. Thus, it seems clear that runoff may either be funneled into burrows, or there may be

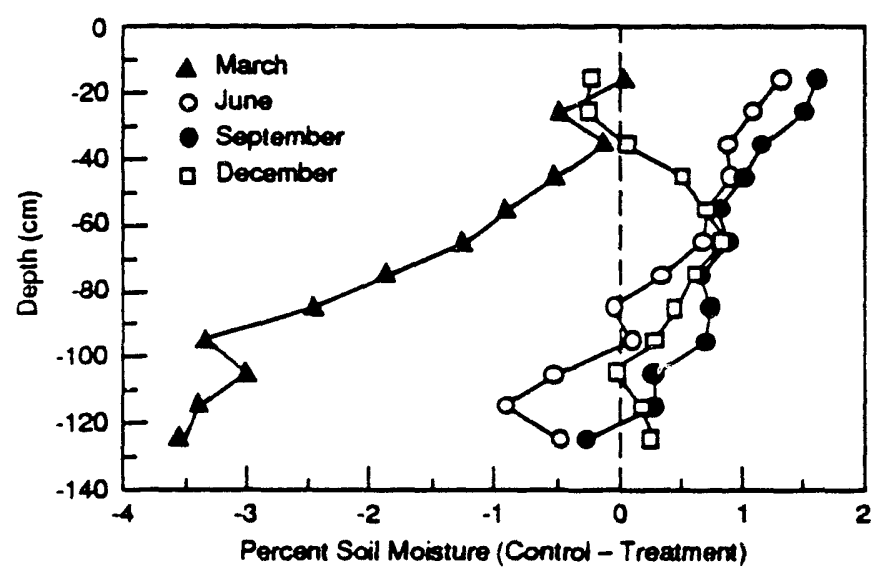

Figure 2.3. Mean Seasonal Change (\%) in Soil Moisture Around Badger Burrows at the End of Each of the Four Calendar Quarters for 1989 increased infiltration in the soil around burrow openings or both.

\section{ROOTINTRUSION STUDIES: DESIGN AND INITIAL SAMPLES}

J. L. Downs, S. O. Link, and L. L. Cadwell (PNL) and M. R. Sackschowsky (WHC)

Studies related to plant root distribution and plant root uptake capabilities were initiated in FY 1990 to support barrier design activities. Knowledge of rooting distribution and depth for plants expected to establish on the barrier is needed to evaluate barrier design with respect to depth of the fine-soil layer and the ability of the barrier to inhibit root intrusion beyond the fine-soil layer. Understanding the role that roots play in recycling moisture to the atmosphere through uptake and transpiration will aid hydrologic modeling of the barrier.

A test plan for evaluating the role of plant roots in barrier design was drafted in FY 1990 to guide in addressing these concerns. The studies outlined in the test plan will support barrier design by 1) providing soil water dynamics and root interaction data for modeling unsaturated flow in the fine-soil layer, 2) producing design criteria to ensure that planned and inadvertent compaction of the fine-soil layer do not adversely affect root exploitation of the soil layer, and 3) assessing the effectiveness of barrier components in preventing root intrusion.

Studies in support of the first issue were initiated at several sites that had vegetative cover similar to that expected on the barriers. Small-diameter $(1-$ in. $)$ root and soil cores were collected at the Lower Snively old field, which is dominated by cheatgrass, Bromus tectorum. This study site is similar in soils and vegetation cover to the old-field site at McGee Ranch. Replicate cores were obtained from plots receiving different water and nitrogenenhancement treatments. These samples are processed by washing the roots from the soil, staining the roots to measure length and area on a digital image analysis system, and weighing the roots to determine root biomass with depth. Samples were gathered early in the spring season (March 1990) and at the end of the spring growing season (May 1990) to compare root growth response to the enhanced conditions with root growth response to normal growing conditions.

Studies were also initiated at the McGee Ranch finesoil site to determine root distribution with depth under the mixed shrub and grass cover. A $1-\mathrm{m}^{2}$ area of a trench wall was mapped to evaluate root distribution in 
each of these areas: directly below big sagebrush, Artemisia tridentata, directly below spiny hopsage, Grayia spinosa, and in the intershrub spaces where annual and perennial grasses dominate. Examples of these maps (Figures 2.4, 2.5, and 2.6) show that grass roots dominate the soil layers above $20 \mathrm{~cm}$, while shrub roots are present throughout the 1-m soil profile mapped even under the grass cover.

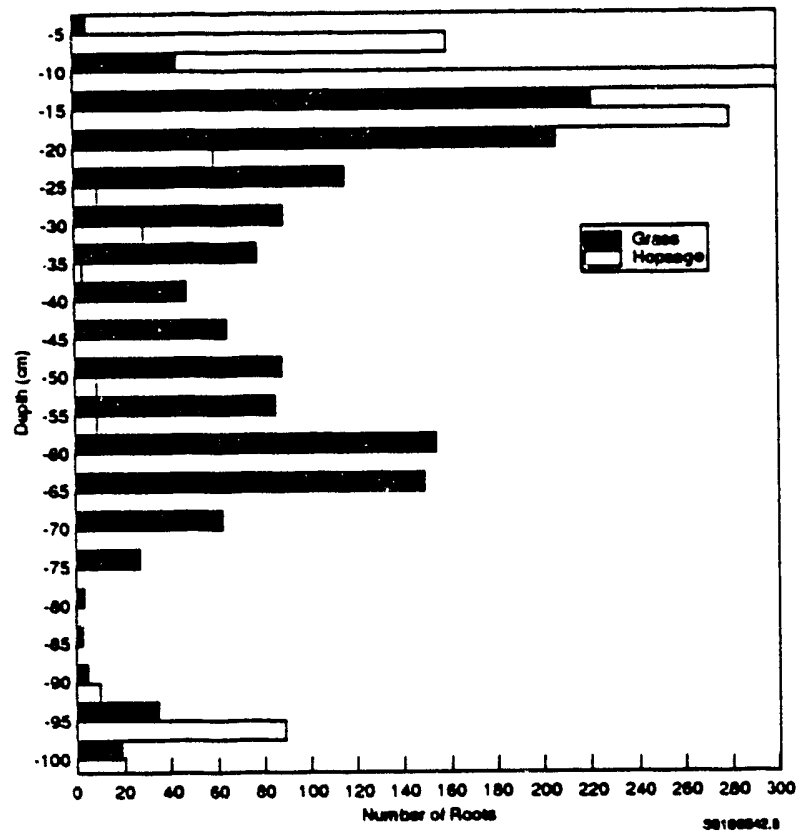

Figure 2.4. Root Distribution in Hummock Area McGee Ranch Hor sage Cover

Root and soil cores were taken in addition to these maps to better delineate root distribution beneath the shrub cover. These 2-in.-diameter cores were taken on hummocks where hopsage dominates, in swales where sagebrush is found, and in swales where no sagebrush occurs. Processing these soilroot cores provides quantitative information on root length density and distribution down to $2 \mathrm{~m}$. This information will be valuable in evaluating the potential for root intrusion and in efforts to model water movement through the fine-soil layer.

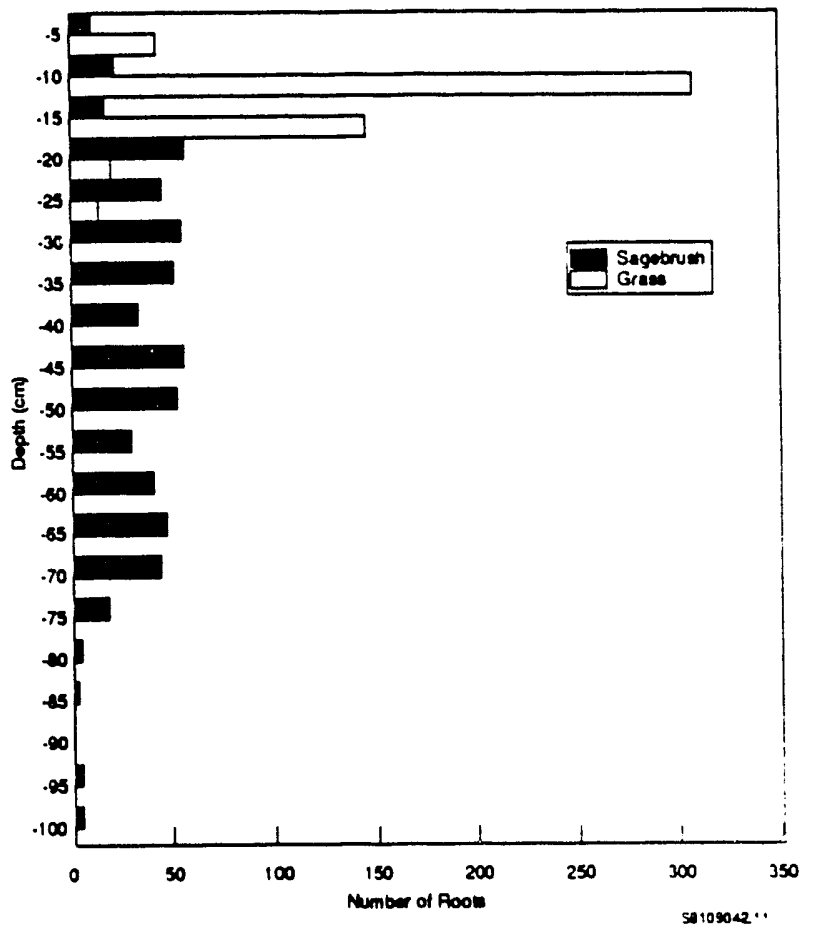

Figure 2.5. Root Distribution in Interhummock Area McGee Ranch Sagebrush Cover

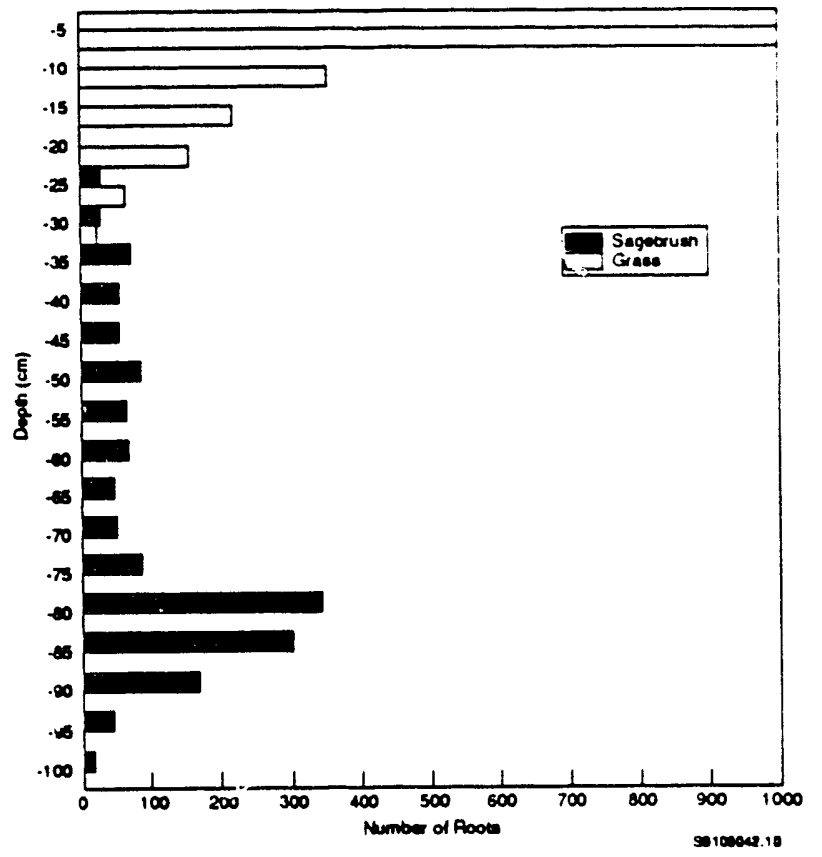

Figure 2.6. Root Distribution in Interhummock Area McGee Ranch Grass Cover 


\subsection{WATER INFILTRATION CONTROL}

Percolating surface water can carry contaminants from waste disposal sites through the biosphere unless the waste sites are isolated by 1) barriers, 2) vitrification, or 3) deep repository disposal. This section describes results of tasks designed to study the effectiveness of barriers in isolating wastes from percolating surface water.

\section{FIELD LYSIMETER TEST FACILITY M. D. Campbell (PNL)}

The Field Lysimeter Test Facility (FLTF) designed by PNL and WHC was built by Kaiser Engineers Hanford during FY 1987. The FLTF is operated by PNL to measure the effectiveness of protective barriers in isolating radioactive wastes from percolating water (Kirkham et al. 1987; Gee et al. 1989; Campbell et al. 1990; Campbell and Gee 1990).

The Record of Decision 53 FR 12449-53 that commits to placement of protective barriers provides for isolation of the radioactive waste from the biosphere. The FLTF lysimeters test seven protective barrier treatment combinations for water exclusion. Detailed measurements of precipitation, evaporation, storage, and drainage are being made.

Hydraulic barriers at the FLTF are at the interface of silt loam soil with sand. This textural break increases the water-holding capacity of the overlying soil. Results of recent studies showed that gravity moved water downward when the upper profile of the silt loam soils exceeded 26 vol\%. The textural break stopped water from draining from the silt loam soil until the soil was wetter than about 38 vol\%. Thus, soil water capacity increased about 12 vol\% above normal as a result of barrier influence. Water loss from bare soil was half as fast and half as much as loss from vegetated lysimeters.

Subsequent obsenvations with clear tube lysimeters showed that roots from Artemisia tridentata grow to the depth of moist soil, and that without a hydraulic barrier. roots from a small transplant reach the bottom of 3-m deep lysimeters in one season. Thus, roots penetrated to the bottoms of $3-\mathrm{m}$ lysimeters and extracted available moisture, even with three times average precipitation. Notably, no liquid water drainage occurred through, the hydraulic barrier, even with three times average precipitation and no vegetation. However, lysimeters configured without a barrier, but with sandy soil and a 20-cm gravel cap, yielded nearly quantitative drainage. Water removal to about 10 vol\% was apparent on all vegetated treatments with silt loam soil, irrespective of irrigation.

Drainage occurred from both irrigated and non-irrigated lysimeters containing silt loam soil, but only during the driest period of the year, apparently as a result of vapor-phase transport alone. The observed drainage closely approximated the predicted downward vapor transport computed from data on thermal gradients and ambient water contents. Liquid transport was ruled out because drainage was equal from lysimeters receiving ambient and twice-average precipitation, and the ambient treatment soils never reached water contents above $2 \mathrm{C}$ vol\%, thus precluding liquid-phase drainage. Figure 2.7 shows that lysimeters drained only during the driest part of the year and only following the maximum favorable thermal gradients.

PLANTTRANSPIRATION/EVAPOTRANSPIRATION S. O. Link, M. E. Thiede, J. L. Downs, D. J. Lettau, and T. R. Twaddell (PNL) and R. A. Black (Department of Botany, Washington State University)

Evapotranspiration is the combined loss of water from plants and soil surfaces to the atmosphere and is a process that must be predictable to adequately model soil waterdynamics. This section describes the results of technological developments and experiments at the Tube Lysimeter Experiment (TULE), Lower Snively Field, Snively Canyon, and the Field Lysimeter Test Facility (FLTF) for research leading to the prediction of evapotranspiration in support of the Protective Barrier Development Program. We were able to measure evaporation, evapotranspiration, and carbon dioxide exchange rates from the TULE lysimeters in the soil surface with and without cheatgrass, Bromus tectorum. Evapotranspiration was higher on the lysimeters with cheatgrass than on the lysimeters with bare soil (Figure 2.8). Leaf area of cheatgrass was positively correlated with evapotranspiration rates. 

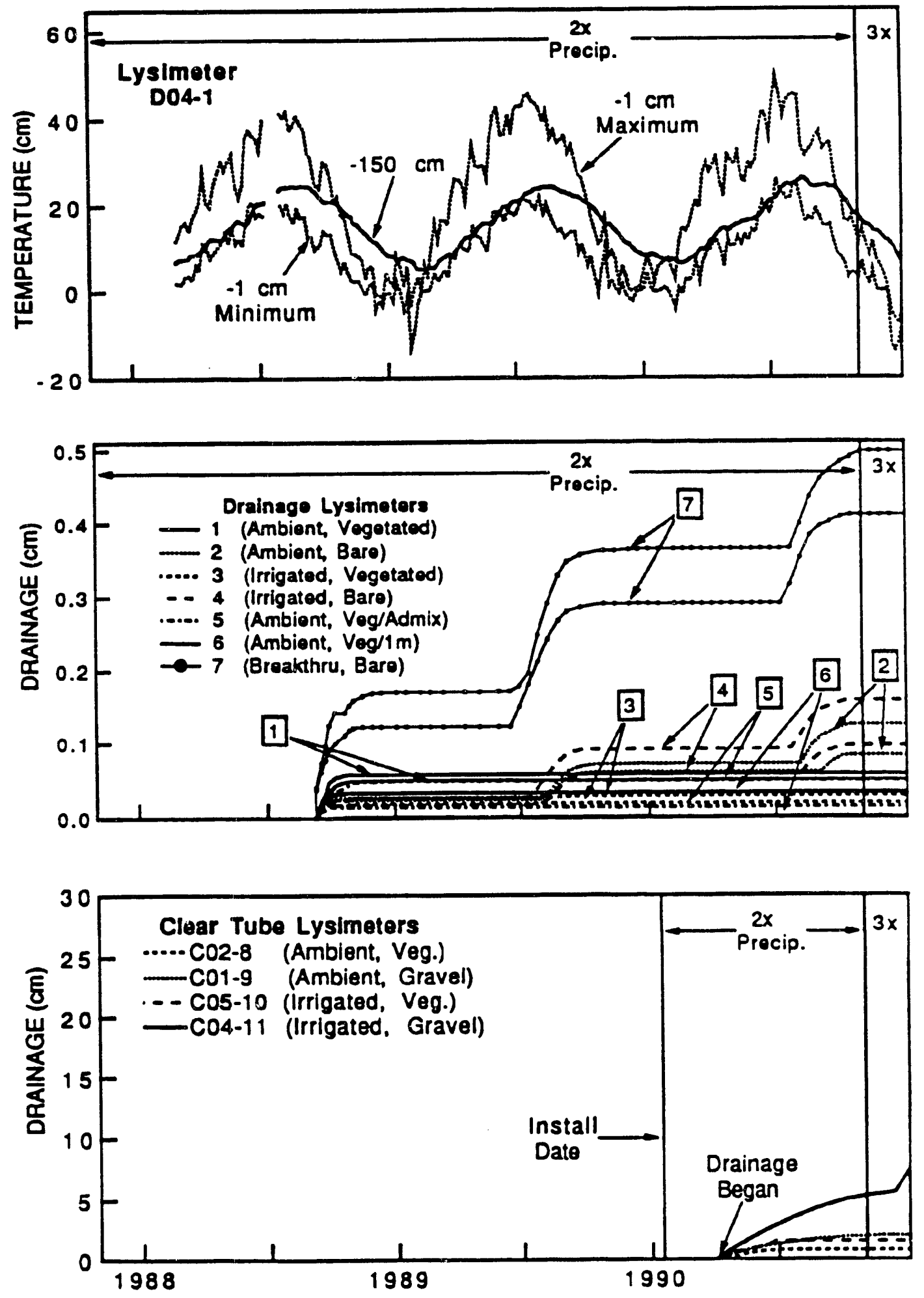

Figure 2.7. Lysimeter Drainage Linked to Temperature, Except for Sand Without a Hydraulic Barrier Present. Clear tube lysimeters 1, 2, 4, and 5 had sand and no hydraulic barrier. 


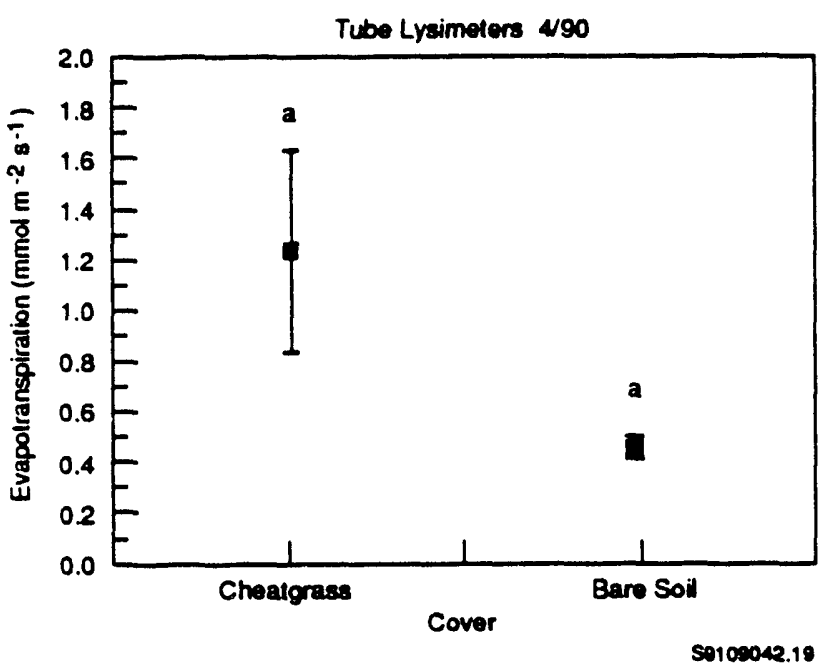

Figure 2.8. Tube Lysimeters April 1990

Growth dynamics of cheatgrass as a function of water and nitrogen treatments were documented at Lower Snively Field from October 1989 through May 1990. Green leaf area index and green shoot biomass were measured monthly over that period. Very little change in shoot growth was observed until April when temperatures warmed. Adding water and nitrogen increased growth when they were added singly, but when added together, growth increased much more. Plant size is one factor that influences the rate at which water is transpired back to the atmosphere (Figure 2.9). Thus, we initiated studies to develop simple growth models that will support efforts to predict soil water dynamics for the protective barrier.

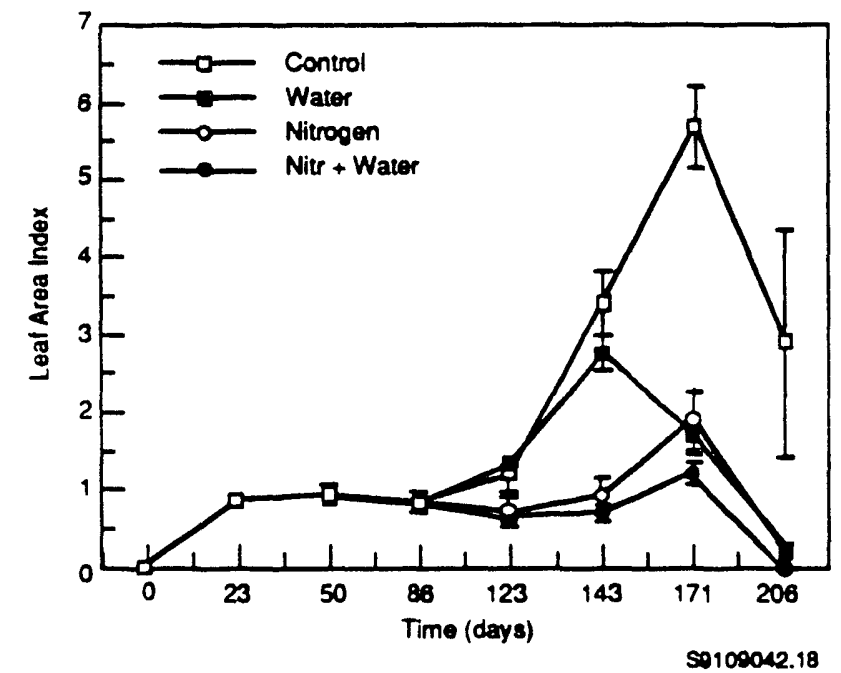

Figure 2.9 Plant Size as a Factor Influencing Transpiration
The whole plant gas exchange system was used to develop simple models of transpiration and carbon gain for cheatgrass growing at Snively Canyon. The relationships between stomatal conductance and net photosynthesis and the driving variables of light, vapor pressure gradient, temperature, and xylem pressure potential were parameterized. These equations were used to predict transpiration (Figure 2.10) and net photosynthesis for days in June. The models successfully predicted these processes.

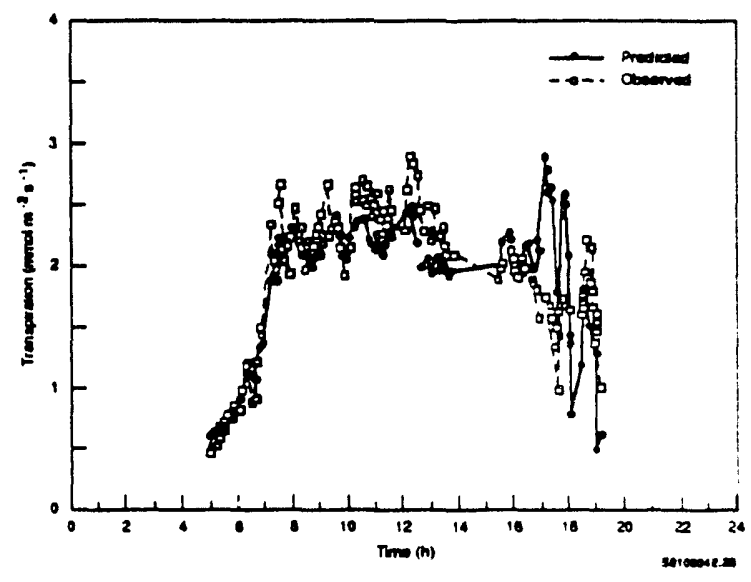

FIGURE 2.10. Cheatgrass in Snively Canyon June 1990

Finally, we initiated research efforts with R. A. Black of Washington State University to measure transpiration of big sagebrush, Artemisia tridentata, growing on the FLTF precision weighing lysimeters. The heat flow technique that measures stem flow in woody plants was able to measure transpiration rates in sagebrush. The technique will make it possible to observe transpiration rates of sagebrush continuously without disturbing the environment of the shoot or the roots.

Future research will entail the parameterization of relationships between evapotranspiration, transpiration, soil evaporation, carbon dioxide exchange, growth, and the abiotic and biotic factors that drive these processes for model development for cheatgrass, bunchgrasses, and shrubs.

\section{DIVERSION BARRIER TESTING}

\section{Asphalt Layer Tests H. D. Freeman (PNL)}

Activities for the asphalt barriers task during FY 1990 consisted mainly of monitoring existing small tube 
lysimeters, installing five new lysimeters using a clear acrylic tube, and defining specifications for the asphalt layer of the prototype barrier.

The eight asphalt and two control lysimeters installed at the Small Tube Lysimeter Facility (SLTF) in 1988 were monitored monthly for weight changes and drainage. Four lysimeters contained a $1.5-\mathrm{cm}$ rubberized asphalt membrane, four contained an admixture of asphalt emulsion and concrete sand, and the two control lysimeters contained only concrete sand. All lysimeters had a $15-\mathrm{cm}$ surface treatment of gravel mulch, which enhances water infiltration. The lysimeter weight and drainage data were used with the measured precipitation at the nearby HMS to estimate water balance of each lysimeter. A summary of these data for two time perperiods, before and after sagebrush planted on four of the lysimeters, are shown in Figures 2.11 and 2.12. These figures show that the cumulative storage in all lysimeters from July 1988 through November 1989 was positive, while the lysimeters containing sagebrush from November 1989 through July 1990 were all negative. These results illustrate the importance of vegetation in recycling infiltrating water back to the atmosphere.

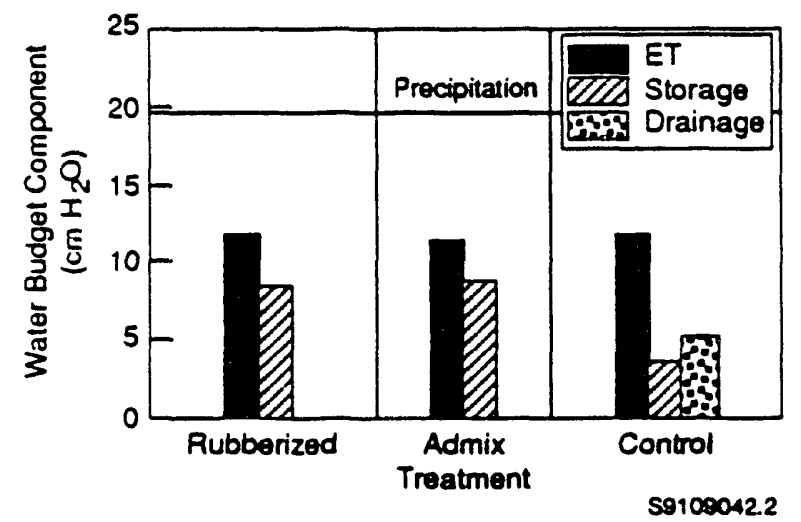

Figure 2.11. Water Balance for the Asphalt and Control Lysimeters During July 1988 - November 1989

Small amounts of drainage were observed in several of the asphalt lysimeters. The source of the drainage could be from water originally added to sand below the seal or from the water in the asphalt emulsion used for the admix seals. Because the origin of the water was difficult to discern, a solution of saturated $\mathrm{NaCl}$ was injected above each seal to act as a tracer. The drain water was then collected and monitored each month by measuring the conductivity of the drain water. The

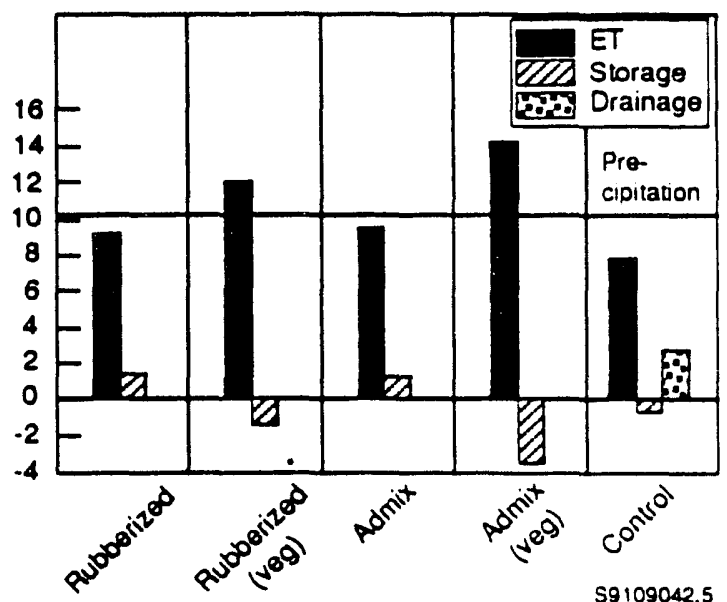

Figure 2.12. Water Balance for Asphalt and Control Lysimeters During November 1989 - July 1990

conductivity was compared with drain water collected from each lysimeter before the saturated salt solution was injected. As of October 1990, the conductivity of the collected drain water from the asphalt lysimeters had not changed significantly from the base period. This indicates the origin of the drain water was not from above the asphalt seal. The control lysimeter that had tracer injected, however, showed extremely high conductivity in the drain water. This proves that the tracer salt is free to move through the Hanford sand and is not immobilized through adsorption or reaction with the soil.

Five new lysimeters, constructed of clear acrylic to allow any leaks and root intrusion to be visually monitored, were added to the STLF during FY 1990. Four of the new lysimeters contained rubberized asphalt membranes with the same layering sequence as the existing rubberized asphalt lysimeters, and one contained Hanford Site sand for use as a control. No leaks or drainage was observed during the first 2 months of exposure. Sagebrush was transplanted to all of the new lysimeters in November 1990. The control and one other lysimeter were also instrumented with thermocouples at $1,15,50,100,125$, and $150 \mathrm{~cm}$ to monitor the temperature profiles for comparison with a similar set of thermocouples placed in the soil outside of the lysimeter. Comparing the temperature profiles of the lysimeters in relation to natural soil allows the magnitude of warming and cooling of the lysimeters from the air gap around each lysimeter to be evaluated. It is hypothesized that the thermal cycling of the lysimeters may affect the water balance observed in the lysimeters. 
Clay and Chemical Grout Tests

M. J. Sackschowsky and C. J. Kemp (WHC)

L. L. Cadwell and M. E. Thiede (PNL)

Using clay and chemical grout components to control infiltration of water through the protective barrier is currently being evaluated by the Hanford Site Protective Barrier Development Program. Tests are being conducted in smali tube lysimeters at the Small Tube Lysimeter Facility. The purpose of these lysimeter tests is to evaluate the performance of a clay component (25\% bentonite clay, $75 \% \mathrm{McGee}$ soil) and a chemical grout component ( $25 \%$ sodium silicate solution mixed with McGee soil to form a pourable grout mixture, about $30 \%$ water by volume) under twice average precipitation. Five small tube lysimeters are being used to test each of these alternative barrier components.

Each lysimeter used in the tests of clay and chemical grout consists of a $15-\mathrm{cm}$-thick course pitrun gravel layer covered with a $30-\mathrm{cm}$ layer of either clay or chemical grout. A $120-\mathrm{cm}$ layer of McGee soil is placed on top of the infiltration barrier. The performance of these infiltration barrier lysimeters is compared with control treatments consisting of either a "bimodal" capillary break configuration or a graded sand configuration. All lysimeters in this experiment are kept free of vegetation and receive enough irrigation to result in a total water input equal to twice the long-term average precipitation.

In FY 1990, no significant differences were found in the total evapotranspiration or total storage change among any of the treatments (Figure 2.13). Total

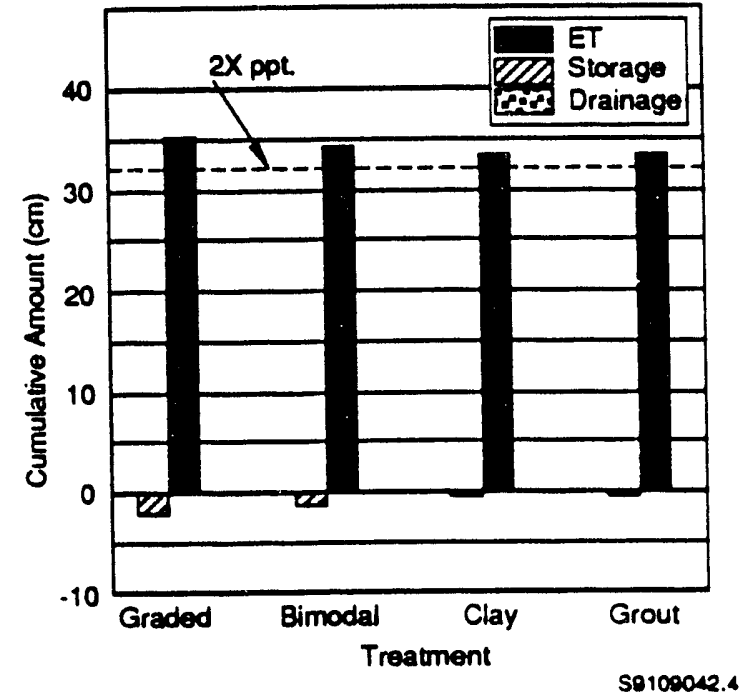

FIGURE 2.13 Alternative Barriers Component Values from July 1989 - July 1990

evapotranspiration exceeded total water input for all treatments, thus the observed decrease in total water storage over the period July 1989 to July 1990. No drainage was observed from any of the lysimeters.

From these results, we conclude that the infiltration barriers and the different capillary break configurations all perform very well under twice average precipitation conditions. We also conclude that these subsurface infiltration barriers have not been "stressed" by the amount of precipitation applied. Future plans include increasing the amount of irrigation to increase the probability of detecting performance differences among the treatments. 


\subsection{EROSION/DEPOSITION CONTROL}

Several studies funded by the Protective Barrler Development Program are testing surface additions of gravel mulches and admixtures for long-term control of wind and runoff erosion. Although adding gravel to the barrier topsoil may control erosion, It was uncertain as to whether it would also compromise the capacity of a barrier to cycle water back into the atmosphere.

\section{FIELD STUDY OF GRAVEL ADMIX, VEGETATION, AND SOIL \\ L. L. Cadwell, M. E. Thiede, M. J. Harris, P. B. Test, V. Parks, and S. O. LInk (PNL), C. J. Kemp (WHC) W. J. Waugh (Geotech)}

This field study was designed to measure the effects of gravel admixtures on soil water storage and plant abundance. Field plots were installed in the fall of 1986 on the site selected as a source of topsoil for protective barrier experiments, and ultimately, for the full-scale construction of barriers at Hanford. Gravel admixture, vegetation, and enhanced precipitation treatments were randomly assigned to the field plots using a split-splitplot design structure. The admixture treatments included no gravel, a $20-\mathrm{cm}$ admixture of $15 \%$ by weight pea gravel $(1.0 \mathrm{~cm})$, and $30 \%$ pea gravel. Twice average precipitation was added monthly to half the plots to simulate a wet climate. Changes in soil water storage have been monitored monthly with neutron moisture meters since 1986. Spring and fall plant cover have been sampled using an ocular point-intercept method since 1987.

Vegetation cover has increased annually through 1989 on both soil and gravel admix surfaces with only slightly greater, but not significantly different, cover on the gravel admix treated surfaces (Figure 2.14). However, twice the normal precipitation resulted in significantly greater cover. Water storage for the plots receiving only ambient precipitation has, in general, declined since the inception of the study in 1986. However there are seasonal variations in soil water storage as well as year-to-year variations. For the period July 1, 1989, through June 30,1990 , total profile storage actually increased (the top $1.25 \mathrm{~m}$ plus the underlying $1.5 \mathrm{~m}$ Figure 2.15). The increase appears to be the result of variations in the amount and timing of precipitation and is likely to be transient. Vegetated plots with gravel admixtures have shown storage changes equivalent to the plots with soil-only surface treatments. Thus, our data suggest that admixtures can be included in waste cover designs to control soil loss without influencing the extraction of soil water.
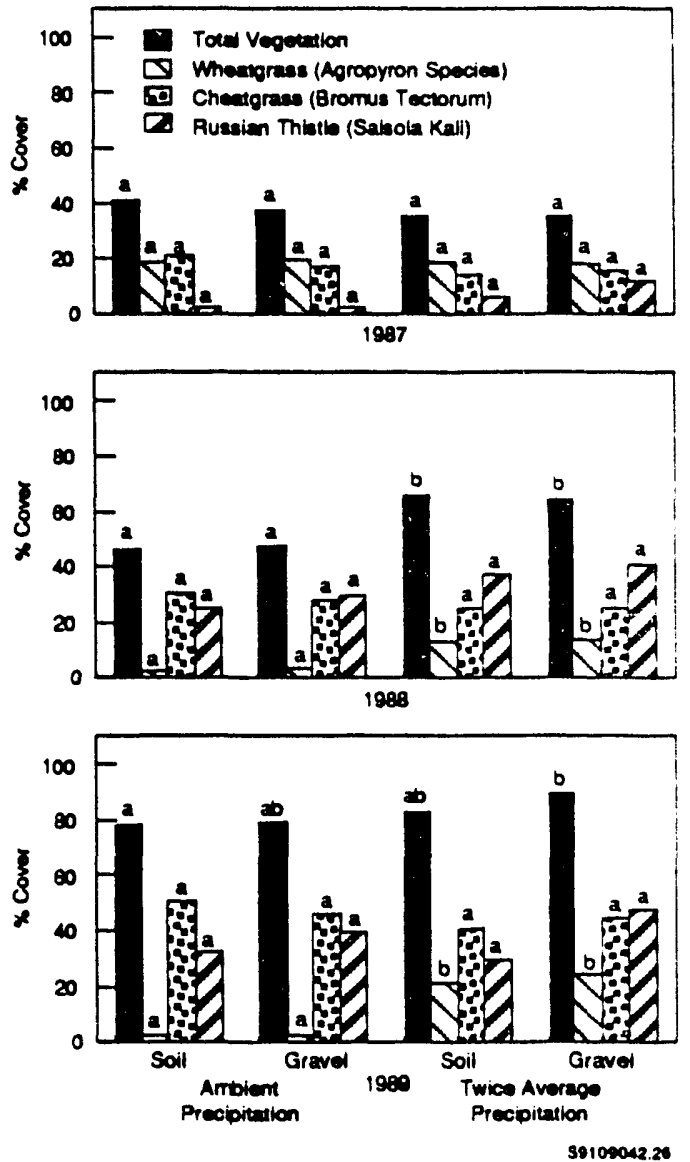

Figure 2.14. Vegetation Cover (\%) for Soil and $30 \%$ Admix Treatment Plots for the Years 1987, 1988, and 1989

\section{SMALL TUBE LYSIMETER TESTS \\ M. R. Sackschowsky and C. J. Kemp (WHC)}

L. L. Cadwell and M. E. Thlede (PNL)

The Small Tube Lysimeter Facility (SLTF) was constructed to measure the influence of erosion control practices and altemate barrier layer configurations on soil water balance. The facility was completed in September 1988, and data have been collected for the last 2 years. To improve the facility, in 1990 insulating collars were installed around each lysimeter. The collars allow the lysimeter soil temperature to more closely 

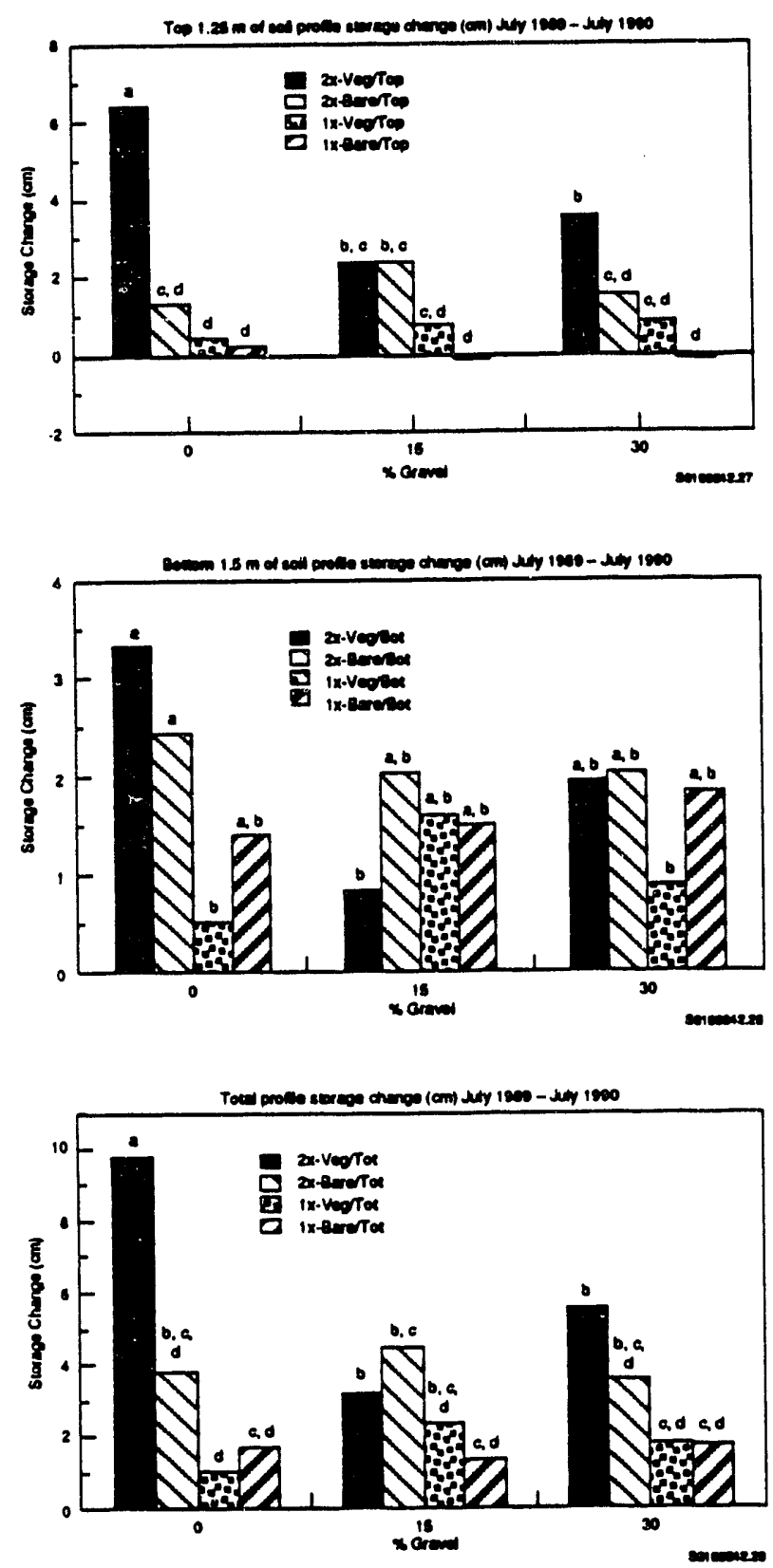

Figure 2.15. Soil Moisture Storage Change Within the Top (125 cm), Bottom (150 cm), and Total Profile (275 $\mathrm{cm}$ ) for Vegetated and Bare Surface with Natural (1X) and Twice Average (2X) Precipitation Treatments for 0,15 , and 30 Percent Gravel in the Surface Soil

track the ambient soil temperatures, thus decreasing bias because of temperature differentials and gradients.

Experiments conducted in the facility are devised to measure the effects of surface gravel admix (gravel uniformly mixed into the top $20 \mathrm{~cm}$ of soil) and gravel mulch, sand deposition, twice the average monthly precipitation, presence or absence of vegetation, and two types of subsurface capillary break configurations on water storage, evapotranspiration, and drainage. The array of small tube lysimeters for the experiments consist of 21 rows of 5 lysimeters each that are irrigated, weighed, and checked monthly for drainage.

In tests conducted in FY 1989 and FY 1990, 60 lysimeters were used to examine the effects of gravel admixtures and gravel mulch. Ten tubes were used to test the effects of a surface sand deposition layer, and 10 to test the effects of pitrun gravel versus a gradedfilter layer as a capillary break. The remaining 25 lysimeters were used in a companion alternate barrier test of asphalt, clay, and chemical grout infiltration barriers.

In the surface treatment experiment, the total amount of evapotranspiration exceeded the total amount of precipitation in all the plain soil and gravel admix treatments, resulting in a net decrease in soil column water storage from July 1989 to July 1990 (Figure 2.16). All the gravel-mulch-covered lysimeters had a net increase in total water storage over this time period, except the vegetated, ambient precipitation treatment. These lysimeters had increased in storage during the previous year, and we believe that the vegetation took advantage of this excess moisture. Overall, vegetative biomass was relatively low, but vegetation resulted in a small but significant amount of water loss by transpiration.

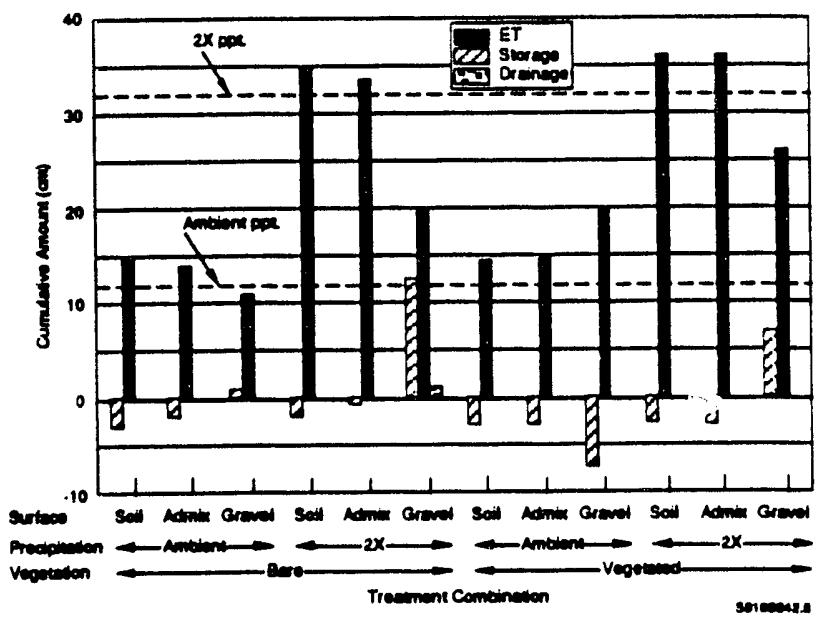

Figure 2.16. Surface Treatment Component Values from July 1989 - July 1990 
Increased precipitation also permitted an increase in evapotranspiration, but had little effect on total storage for either the plain soil or the gravel admix surface lysimeters. Therefore, these treatments eventually lost almost all the additional water by evapotranspiration. Gravel mulch surface lysimeters had a significantly gieater amount of storage with irrigation compared with ambient precipitation lysimeters, suggesting that most of the additional water input is initially stored in the column and will eventually be lost through drainage. Drainage was only observed in the irrigated gravel treatments.

A sand deposition layer on the lysimeter surface had much the same effect as a surface layer of gravel mulch (Figure 2.17). The total evapotranspiration was less than the total amount of irrigation plus precipitation, resulting in a net increase in total storage. The presence of vegetation increased the amount of evapotranspiration and decreased the amount of total storage. Drainage was detected from lysimeters in both the vegetated and bare sand-covered lysimeters.

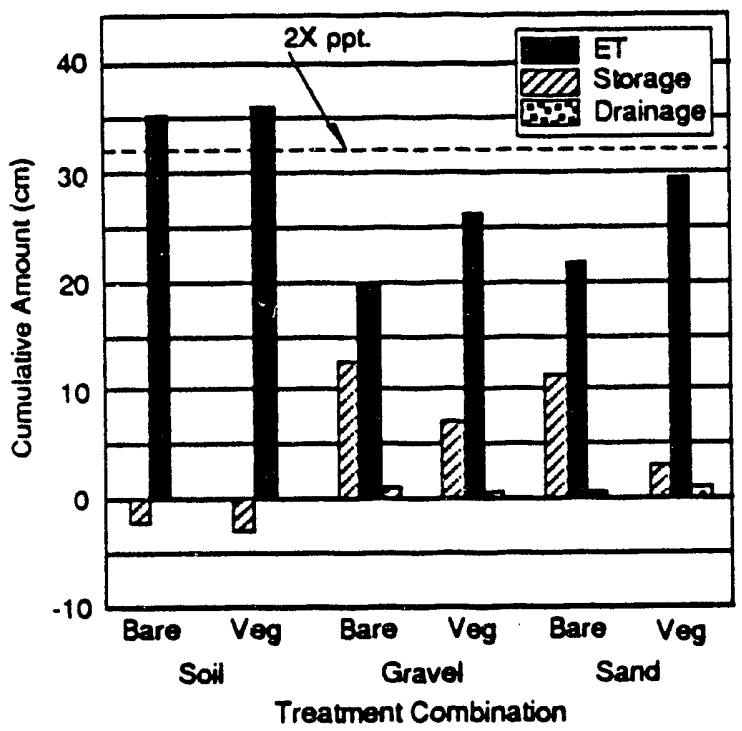

Figure 2.17. Bimodal Versus Graded Layering Component Values from July 1989 - July 1990

At this point, no discernible differences in soil moisture dynamics exist between the bimodal (McGee soil overlying pitrun gravel) or graded filter (MCGee soil over fine sand) capillary break configurations (Figure 2.18). Evapotranspiration from all treatment lysimeters exceeded total water input, and no drainage was detected from any of these lysimeters.

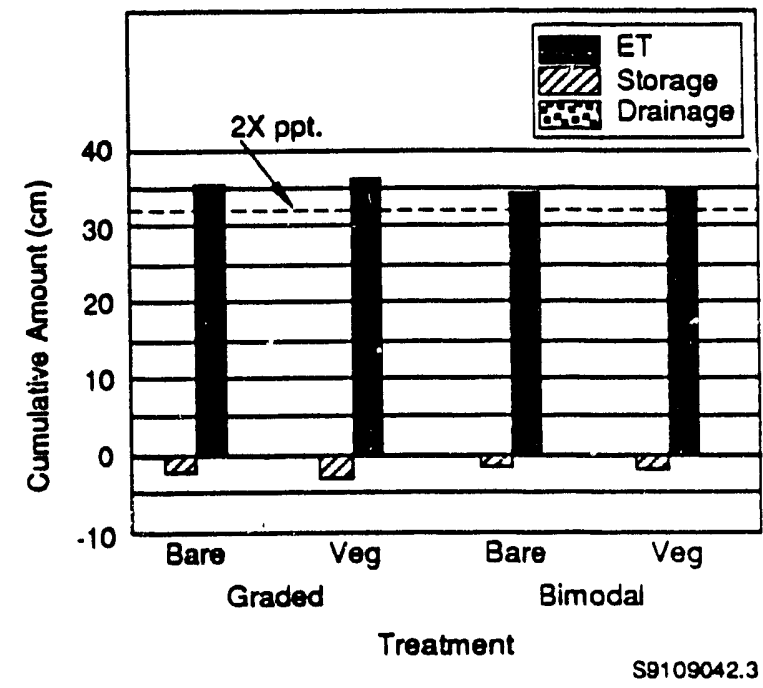

Figure 2.18. Surface Treatment Component Values from July 1989 - July 1990

In future studies, the amount of irrigation will be increased, allowing us to detect performance differences among the various treatments, especially the bimodal and graded-filter comparisons.

\section{WIND EROSION}

M. W. Ligotke, D. C. Klopfer, and J. F. Cline (PNL)

Maintaining an intact, erosion-resistant surface layer over waste sites is especially important during times of extended climatic stress such as droughts and climates postulated to be caused by increased $\mathrm{CO}_{2}$ levels in the atmosphere (the greenhouse effect). Three eolian processes cause erosion and transport of soil particles by wind: surface creep, saltation, and suspension. Surface creep is the wind-influenced sliding and rolling of particles along the surface. Sattation is the short-distance hopping of very fine sand particles and occurs as wind suction overcomes gravity and electrical charges holding particles on the ground. Suspension is the long-distance transport of soil particles from exposed surfaces. Soil particles are even smaller than very fine sand grains, and while gravity plays little role, the electrical charges between these particles and the ground are very strong, and thus difficult to overcome by wind alone. Soil particles are dislodged from the surface by the process of saltation and to a lesser degree of creep and wind turbulence.

The objectives of wind erosion studies in support of natural material protective barriers are to: 1) develop 
a surface layer composition that will protect the underlying fine soilreservoir during periods of climatic stress, 2) investigate the formation processes of sand dunes and blowouts, and 3) provide data for and develop a predictive model of wind erosion. These objectives are further described below.

1. A wind tunnel is being used to study the stability of surface layers. Surfaces containing silt-loam soil and varied gravels, soil moistures, and surface crusts have been tested. Measured surface deflation rates are compared with the wind-caused surface shear stresses. In addition, a method to characterize the shear stress caused by saltating sand grains was initiated in FY 1990. Continued tests of these eolian and surface parameters are planned, as are tests of the influence of windbome sand deposits, plant canopies and roots (post-wildfire simulation), burrowing animals, and surface microterrain.

2. Large-scale eolian structures such as sand dunes and blowouts may provide a threat to the integrity of long-term protective barriers. If sand dunes form on the surface, plant communities would be displaced, and water from precipitation could migrate through the waste zone. Blowouts caused by scouring winds could reduce the water storage capacity of the fine soil resenoir, provide depressions for water accumulation, and potentially expose lower barrier layers. Studies are planned to investigate the formation processes and methods of control of dunes and blowouts. Potential control methods include stabilizing upwind source sands and using gravel admixtures.

3. The development of a predictive wind erosion model is planned. The model will be used to determine the predominance of deflationary or inflationary fartors, to estimate the impact of dunes and blowouts, and to determine potential loss rates of the fine-soil reservoir as influenced by climatic factors and animal intrusion. Although modification of existing agricultural models will be considered, the parameters used in such models may not be applicable to a wind erosion model for long-term, natural-material protective barriers. Input requirements for a wind erosion model will include long-term climate scenarios.

Results of FY 1990 wind tunnel studies included 1) comparisons of the influence of sands and gravels on surface deflation rates, 2 ) initial soil moisture and surface crust data, and 3) the influence of induced saltation. Although the addition of small-diameter gravels $(0.2$ to $1 \mathrm{~cm})$ decreased erosion rates to about $2 \%$ of those from unprotected soil surfaces, the inclusion of fine and medium sands increased deflation rates to between 3 and 10 times those from unprotected soil surfaces. This is important because wind-deposited sand grains are particularly susceptible to wind erosion and can, in saltation, increase erosion rates of soil particles. An initial series of soil moisture tests provided a relationship between the moisture content of the surface layer (SMC in \%) and surface deflation rates (DR in $\mathrm{g} /\left[\mathrm{m}^{2}\right.$-s]): $D R=$ $14.7(\mathrm{SMC})^{-1.73}, R^{2}=0.88$. The measurements were performed over a surface SMC range of 0.7 to $5.5 \%$, measured to a depth of $3 \mathrm{~mm}$, and deflation rates ranged between $31 \mathrm{~g} /\left(\mathrm{m}^{2}-\mathrm{s}\right)$ and $<0.6 \mathrm{~g} /\left(\mathrm{m}^{2}-\mathrm{s}\right)$. The deflation rates from simulated raindrop-impact crusts exposed to only wind stress were too low to measure, but were estimated to be less than about $\left.\left.0.01 \mathrm{~g}^{2} \mathrm{~m}^{2}-\mathrm{s}\right]\right)$. One crust was then exposed to induced sand saltation at a rate of $28 \mathrm{~g} /(\mathrm{m}-\mathrm{s})$ for three 2 -min periods, and deflation rates of 7,14 , and $21 \mathrm{~g} /\left(\mathrm{m}^{2}-\mathrm{s}\right)$ were measured. The saltation rate used in the test was comparable to drifting dune sand at a 10- $\mathrm{m}$ wind speed of about $14 \mathrm{~m} / \mathrm{s}$ (32 mph). Thus, the stress caused by saltating sand particles was shown to cause raindrop impact crusts to fail and deflation rates to approach those of unprotected soil surfaces.

Sand transport potentials at and near the Hanford Site were estimated and reported as sand roses. Wind rose data were modified using the results of sand transport equations to provide sand drift rate estimates. At the HMS, for example, the yearly average sand drift potential estimate is $0.125 \mathrm{~g} /(\mathrm{m}-\mathrm{s})$, and the yearly resultant sand drift potential estimate is $0.082 \mathrm{~g} /(\mathrm{m}-\mathrm{s})$ from the west. Although the prevailing winds are usually the northwest drainage winds, the fastest wind speeds are associated with the southwesterly wind vector, and as shown in Figure 2.19, can contribute greatly to the resultant yearly average sand drift potential vectors.

Contributions were made to the plan to construct a prototype protective barrier. Design issues included the location and orientation of the barrier, the composition of the surface layer, and the geometry and composition of the upper edge region of the barrier. Field studies were planned to measure surface shear stresses using boundary layer anemometers and surface deflation rates using erosion pins or scour chains and saltation traps. These field studies will provide information on eolian erosion processes and the long-term stability of protective barriers. 


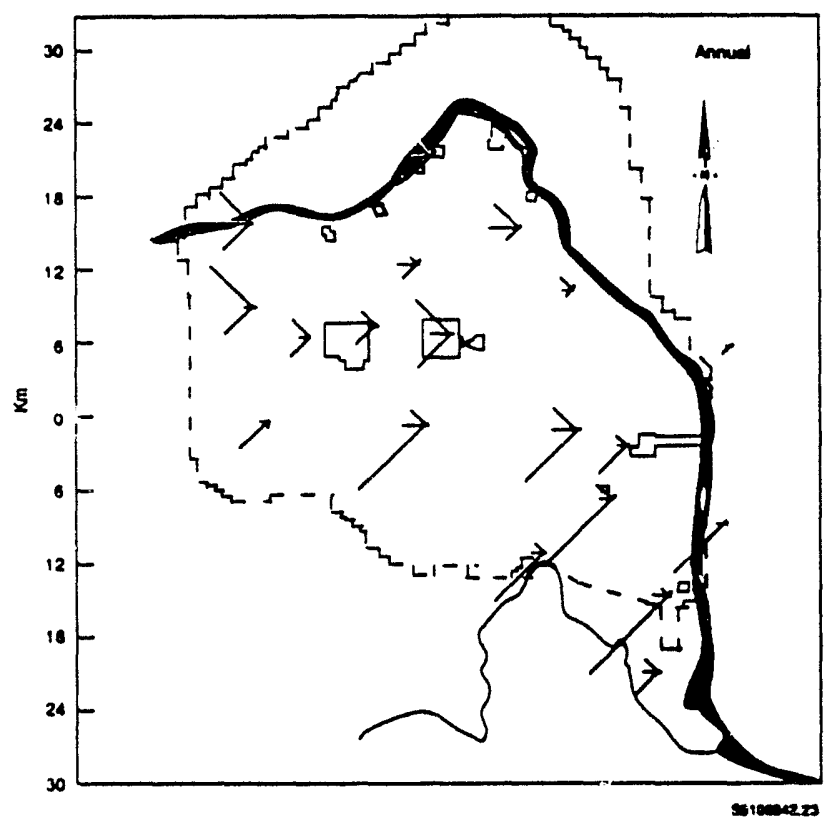

FIGURE 2.19 Annual Sand Roses for the Hanford Site. A line length of $0.5 \mathrm{~cm}$ represents an annualaverage sand drift potential of $0.1 \mathrm{~g} /(\mathrm{m}-\mathrm{s})$. The Hanford Meteorological Station is located just east of the 200 West Area (after Glantz et al. 1990).

\section{WATER EROSION}

\section{W. Walters K. A. Hoover, and L. L. Cadwell (PNL)}

Pacific Northwest Laboratory is conducting water erosion studies to investigate the ability of the barrier top surface, composed of Warden silt loam and basalt rock sideslopes, to withstand the erosional and destabilizing effects of rainfall and runoff.

Field tests initiated to assess the erosion potential of barrier top surfaces were conducted at McGee Ranch, the source location for fine-textured soils planned for use on the barrier's gently sloping top surface. Tests consisted of applying storms of known rainfall characteristics to soils in $1-m^{2}$ plots equipped with flumes to collect runoff water and sediment. The tests used Warden silt loam with three different surface treatments: 1) unmodified silt loam, 2) silt loam soil enriched with up to $80 \%$ silt , and 3) silt loam with gravel admix (soil amended with $30 \%$ by weight pea gravel). The freshly prepared test surfaces were uncrustec and lacked vegetation growth.
The highest runoff rates (Figure 2.20a) and the lowest sediment concentrations (Figure 2.20b) were derived from the gravel admix plots that developed a surface armor layer as fines were lost to erosion. The gravel armor reduced raindrop splash. Raindrop splash appeared to be a significant erosional process that occurred during al! storm events. Some movement of the pea gravel-sized particles occurred. Crust and seal formation appeared to be promoted by proportionally higher silt content on plot surfaces. Crusting developed through a wetting and drying process. Sealing was destroyed during a subsequent storm by raindrop impact and crusts by re-hydration. Crusts alone appeared to inhibit infiltration and promote runoff, which occurred even in the absence of saturated soil conditions.

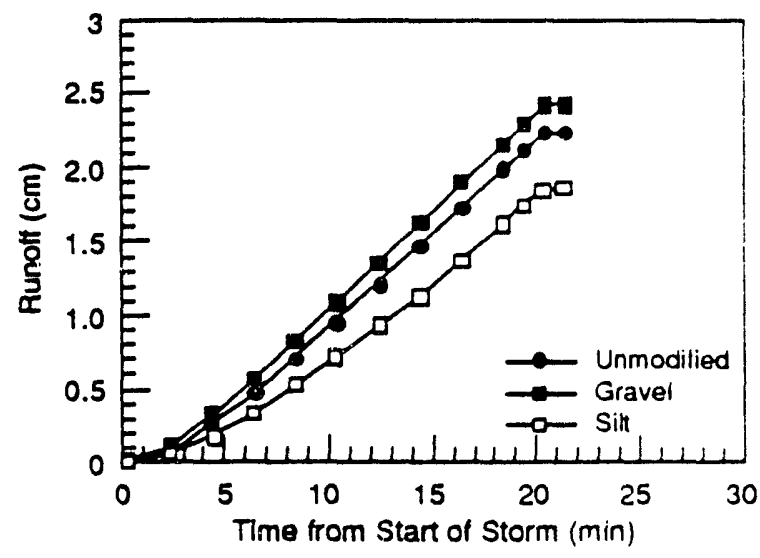

S9109042.15

Figure 2.20a. Runoff Rates for Plot Group 4 During Storm 4

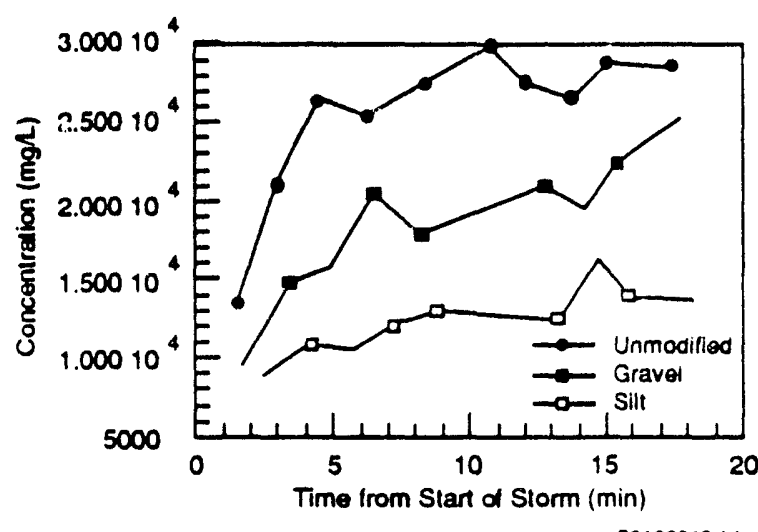

Figure 2.20b. Sediment Concentration in Runoff Plot Group 4 During Storm 4 
Thess preliminary results suggest that gravel admix surfaces have at least one very desirable property for barrier performance. The reduced soil erosion that results at least in part from reduced raindrop splash will contribute to greater surface stability and extended barrier life by protecting the surface covering of the barrier. Additional tests and/or modeling efforts are required to predict amounts of soil that may be lost through time and relationships between soil loss and vegetation establishment for these surfaces. 


\subsection{MODEL APPLICATIONS AND VALIDATION}

The model applications and valldation task uses computer models to predict barrier performance (Fayer 1990). The water balance portion of the task, particularly the drainage component, has been the major focus of the modeling effort. In FY 1990, major efforts were to 1) solve the barrier edge problem with the TOUGH and PORFLO-3 computer codes, 2) verify the ability of PORFLO-3 to simulate infiltration in animal burrows and root channels, and 3) use the TOUGH code to study temperature effects on lysimeter drainage.

\section{MODEL APPLICATIONS AND VALIDATION M. J. Fayer, M. L. Rockhold, and D. J. Holford (PNL)}

The barrier edge problem involves studying the effect of water flowing under the barrier edge from beyond the barrier. The results of this work will eventually be used to optimize the distance that a barrier must extend beyond a waste zone to limit flow past the waste. The results, using three codes, indicate that for a 76-mthick unsaturated zone, a common water-content solution is obtainable, but not a common flux solution as seen in Figure 2.21. The TOUGH code predicted that within 500 years, the flux moving past the waste will be $3.5 \times$ that predicted with PORFLO-3. As time progresses beyond 500 years, all three codes predicted fluxes that would be less than the current barrier drainage standard of $0.05 \mathrm{~cm} / \mathrm{yr}$. Additional work is planned to narrow the prediction differences.

A verification test of PORFLO-3 Version 1.1 was conducted in preparation for using the code to study infiltration into animal burrows and root channels. Axisymmetric solutions of water infiltration using

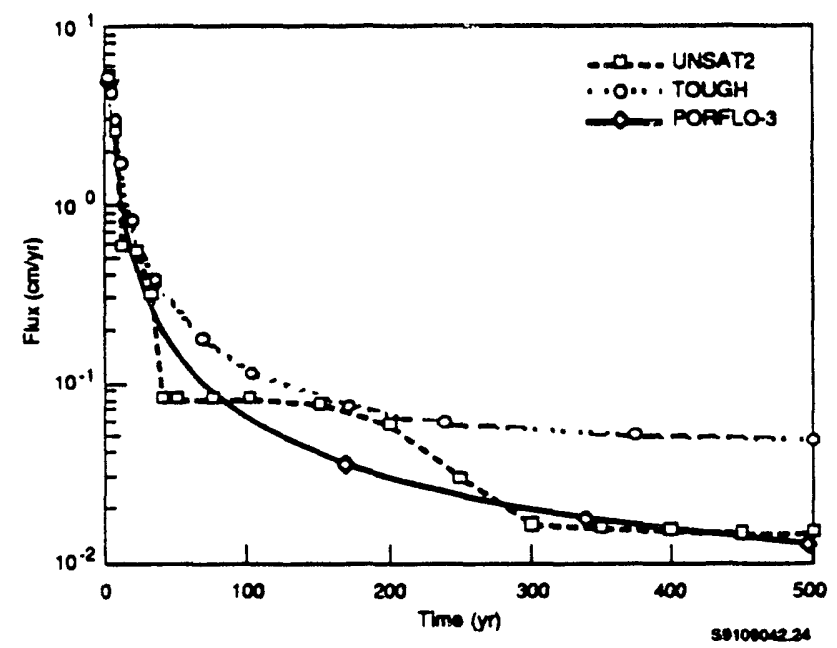

Figure 2.21. Estimated Flux Past the Bottom-Left Corner of the Waste Zone Versus Time
PORFLO-3 were compared with generalized solutions for infiltration from a surface point source. Comparisons of the two solutions were qualitative, given that the code configurations (e.g., node density and arrangement, internodal conductance calculation, surface boundary description) were not identical. Despite the differences in how the problem was solved, the comparisons showed that PORFLO-3 predicted wetting front positions that were comparable to the generalized solutions. For a more quantitative benchmark of PORFLO-3, the TOUGH code will be used to solve this problem. Some difficulties in the comparisons reported here (e.g., node density and arrangement and internodal conductance calculation) can then be eliminated.

The TOUGH code was used to test the hypothesis that temperature changes along the side walls of small tube lysimeters could induce drainage of in situ water located beneath supposedly impermeable asphalt layers (Figure 2.22). Drainage from the lysimeters has been observed yearround, and the peak occurs during the summer. The proposed mechanism for producing

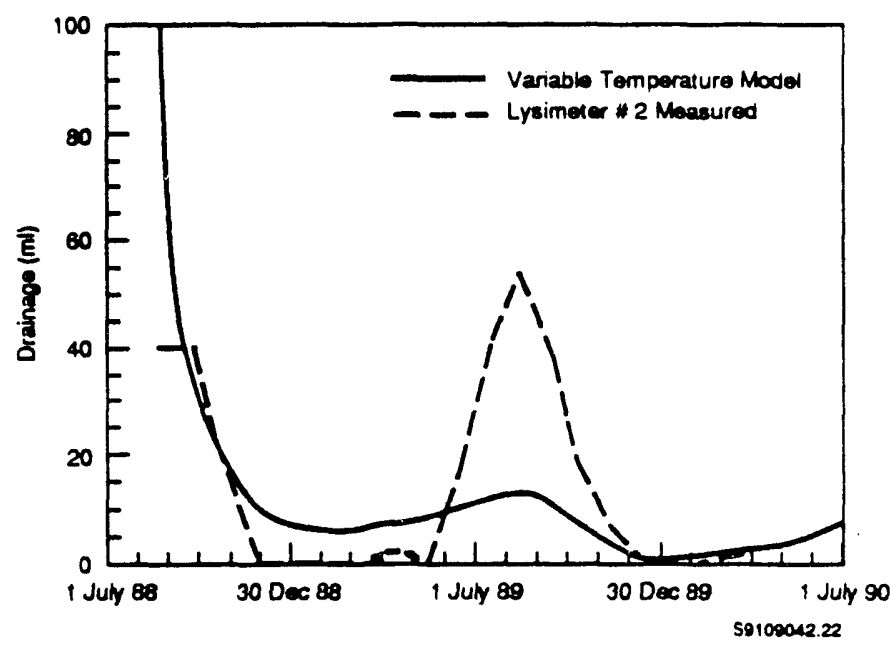

Figure 2.22. Comparison of Drainage Predicted by TOUGH and Measured from Asphalt Barrier Lysimeter 
drainage of in situ water is redistribution of water in the liquid and vapor phases in response to temperature gradients. Using mean monthly soil temperatures measured at a nearby site, TOUGH predicted that some of the in situ water would drain, and that the peak would occur during the summer. The results imply that any lysimeter that has belowground surfaces exposed to uneven temperature changes may be subject to the same effect. The results also imply that temperature effects on protective barriers could be significant and should be calculated. 


\subsection{NATURAL ANALOGS}

The natural analogs tasks of the Hanford Protectlve Barrier Development Program use natural and anthropogenic environments to obtain evidence for projecting the long-term performance of engineered structures. During FY 1990, this project consisted of six tasks. As part of one task a draft report, Barrier Analogs: Long-Term Pertormance Issues, Prellminary Studles, and Recommendatlons was prepared describing the applicability of analogs to long-term performance issues. A test plan was written fer a second task to study analogs of the dynamics of future plant communities and its effect on the effectiveness of barriers at preventing water inflitration. Three of the remaining four tasks entailed field and/or literature studies and are described in detail below.

\section{PEDOGENIC CARBONATE STUDIES}

\section{A. J. Busacca (Department of Agronomy, Washing- ton State University)}

In the soils of arid regions, carbonates tend to be washed from near-isurface sediments and precipitate below the surface : 5 soil water evaporates. Over long periods of unifom cliriate, these carbonates tend to build up, forming carbonated horizons. This task explores the effects that the formation of carbonate horizons in soils may have on the hydraulic characteristics of barriers during the planned period of performance. Two subtasks were conducted in FY 1990. The first was publication of a report, A Feasibility Study of Modeling Pedogenic Carbonates in Soils and Sediments at the U. S. Department of Energy's Hanford Site. (Hunter, Busacca, and Waugh 1990). The second subtask was a pilot project conducted to assess the impact pedogenic carbonate in shallow subsoil horizons may have on infiltration rates of water into the soils, relative to similar soil horizons without carbonate. Two naturally occurring soils whose histories began around 13,000 years ago were described, infiltration of water under natural field conditions was measured using a disk permeameter, and samples were collected for laboratory analysis of their physical properties and moisture release characteristics. Two calcic horizons in the soils had steady-state infiltration rates that were 3-5 times lower than similar, noncalcic soil horizons. One gravelly calcic horizon showed no difference in infiltration from its noncalcic equivalent. These findings show that variation in hydraulic properties resulting from spatial variability of texture and pedogenic cartonate content within individual soil horizons is an important consideration in the design and operation of proposed engineered earthen protective barriers. A draft report was prepared on the FY 1990 progress of that study.

\section{LAYER INTERFACE INTEGRITY J.C. Chatters (PNL)}

This task considers the possibility that pedoturbation processes might disrupt the textural boundary between layers in protective barriers, compromising the capillary break those layers are intended to create. Two subtasks were conducted during this year. The first was a search for analog sites with layering that resemble protective barriers and in which some sort of pedoturbation is evident. The second was an analysis of the possibility that cryoturbation (mixing due to freeze-thaw cycles in permafrost soils) might occur at Hanford in the next 10,000 years, and a search of analog sites. The search for analog sites, which is described in a letter report, Evaluation of Long-Term Stability of Layer Interfaces in Protective Barrier Design: Recommended Natural Analog Sites for Detailed Characterization, resulted in discovery of three sites, where the effects of biotrubation and illuviation of fine sediment into gravels can be studied. The cryoturbation study, described in a letter report. Evidence and Potential for Cryogenic Alteration of Soils within the Pasco Basin, included a literature review on cryogenic effects in soil, and an evaluation of evidence for cryoturbation in the Pasco Basin. The conclusion is that cryoturbation has not been a significant process here during either glacial or interglacial periods.

\section{HUMMOCK/SWALE TOPOGRAPHIC EFFECTS ON SOIL WATER PATTERNS \\ S. O. Link, J. C. Chatters, J. L. Downs, P. B. Test, M. E. Thlede, and G. W. Gee (PNL), W. J. Waugh (cieotech)}

One purpose of waste containment structures is to minimize the infiltration of water into the buried waste. 
An important factor influencing the possibility of drainage through a scil cap is the structure of the soil. Current construction practices impose an unnatural microtopography on a closure cap. In time, though, it is thought that the surface microtopography of a constructed cap could return to the form occurring in undisturbed sites. Many sites from which closure cap soils may be obtained have a complex surface structure that may influence drainage patterns and the distribution of soil water. The area in which this study was conducted has al surface structure that is complex, characterized by coppice dunes in association with spiny hopsage, Grayia spinosa, shrubs.

The objective of this study was to determine if relationships exist between hummock/swale topography and soil vater dynamics under normal and enhanced precipitation regimes. Addressing this objective required detailed information about the topography (electronic distance measurement), aboveground plant community (digitized aerial photos). the soil water profile (neutron probe), and the root distribution and density (root profile mapping) below ground in relation to the topography of the area. To test the hypothesis that surface topography was related to soil water content we used an experimental design in the field that concentrated on apparent major effects.
Three conditions were apparent at this site. These hummocks were dominated by spiny hopsage, bare swales, and swales populated by big sagebrush and grasses. There were 7 replicates in the bare swales and sagebrush swales and 14 replicates in hummocks. To test the hypothesis that additional water would increase soil water pattern differentiation with respect to surface topography we used the same experimental design described above, but without spiny hopsage hummocks and sagebrush swales. The site chosen for irrigation with the rainfall simulator was similar to the unimigated area.

Coppice dune topography and related vegetational patterns (Figure 2.23) appeared to cause patterns in soil water storage and soil water content with depth.

Bare swales were wetter than either hopsage hummocks or sagebrush swales while hopsage hummocks and sagebrush swales were not significantly different. Sagebrush swales were similar to bare swales with respect to soil water storage patterns in time (Figure 2.24). This observation has implications for hydrology models. Accurate representation of soil water dynamics requires the use of multidimensional models. These models have to consider the effect of plants on soil water dynamics The effect of enhanced

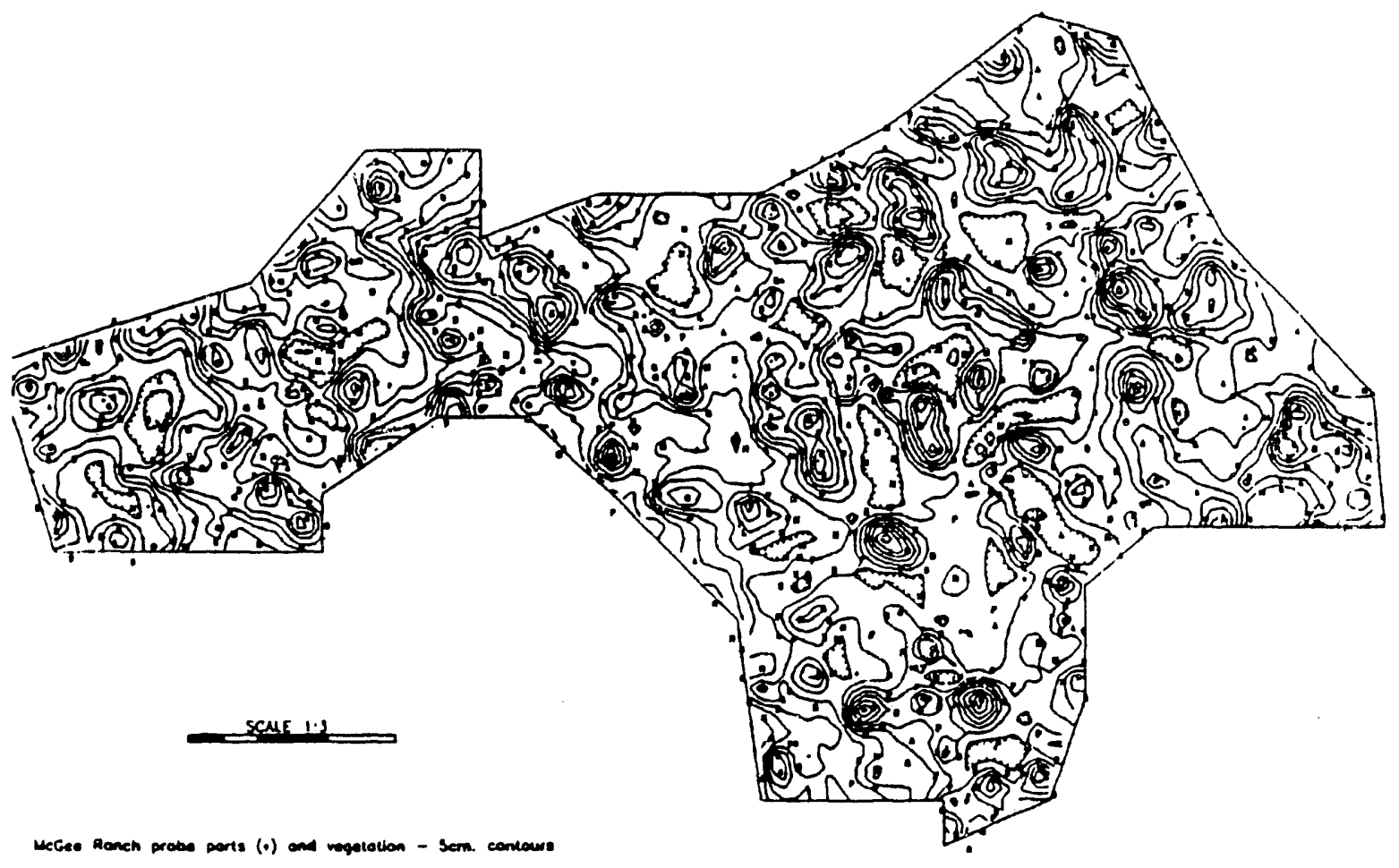

Figure 2.23. Contour Map of the Study Area Showing Hummocks, Swales, and Cover Classification 
precipitation on end-of-season soil water storage and profile pattems in this study was negligible. This semi-arid ecosystem can recycle to the atmosphere at least twice the normal precipitation given that additional water comes in the spring (Figure 2.24).

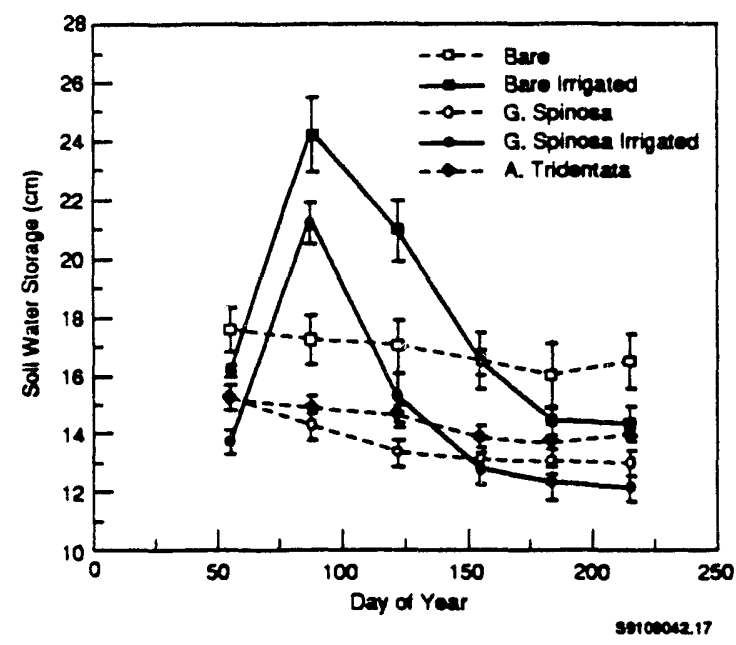

Figure 2.24. Soil Water Storage Dynamics in Bare Swales $(n=7)$, Irrigated Bare Swales $(n=7)$, Spiny Hopsage Hummocks $(n=14)$, Irrigated Spiny Hopsage $(n=7)$ Hummocks, and Sagebrush Swales $(n=7)$. Bars are one standard error of the mean.

The soil water profile 15 days after irrigation indicated that the maximal depth of the wetting front was between 80 and $125 \mathrm{~cm}$ (Figure 2.25).

The soil water profile on day 215 showed that all irrigation water had been recycled to the atmosphere. No clear evidence exists of drainage (Figure 2.26.). The main active zone for soil water and roots was above $125 \mathrm{~cm}$. Below $125 \mathrm{~cm}$ little change was apparent in soil water content over the period varying between 6 and $9 \%$.

Future research at this site will investigate how much additional water can be added to the system before the wetting front passes the deepest observed rooting depth, creating the potential for drainage. This water will be added in the fall while the plants are at

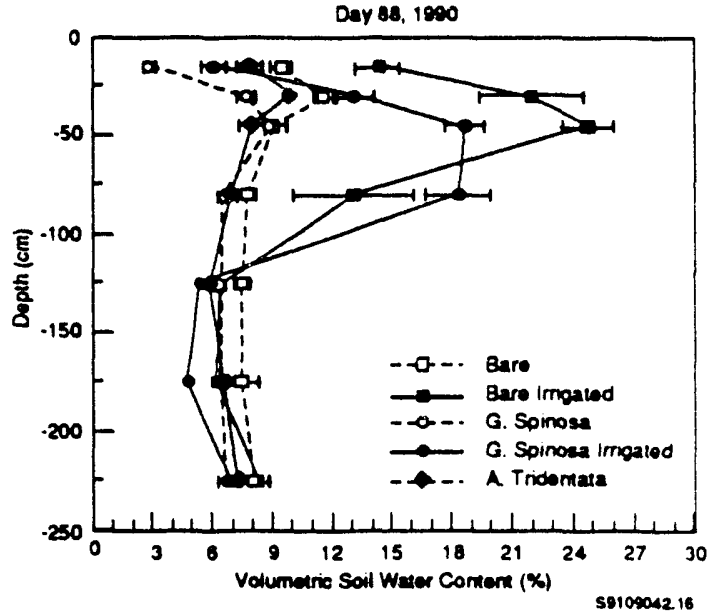

Figure 2.25. Volumetric Soil Water Content (\%) Patterns with Depth on Day 88, 1990

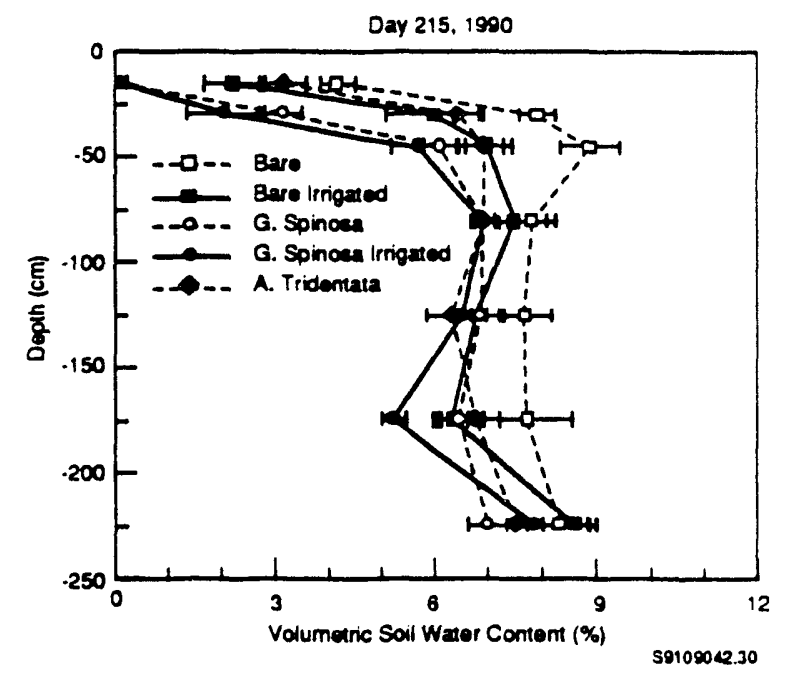

Figure 2.26. Volumetric Soil Water Content (\%) Patterns with Depth on Day 215, 1990

low activity levels. Further work will use stable isotopes to determine if the soil water below $125 \mathrm{~cm}$ is more like recent precipitation or is derived from older waters (old precipitation or ground water). 


\subsection{LONG-TERM CLIMATE CHANGE EFFECTS}

The Long-Term Climate Change Assessment Task is a multiyear program to assess long-term climate change effects on protective barrier performance. The work is being performed in support of the objectives and tasks outllned in the Protective Barrier and Warning Marker System Development Plan and the Protectlve Barrier Climate Change Assessment Study Plan. The effort is a collaboration between scientists and engineers from PNL and WHC to design and test barrler performance in limiting movement of radionuclides and other contaminants to the accessible environment for at least 1,000 years and possiblly as long as 10,000 years.

\section{LONG-TERM CLIMATE CHANGE EFFECTS K. L. Petersen (WHC) and J. C. Chatters (PNL)}

A multi-disciplinary approach to climatic data acquisition is being relied on to obtain defensible climatic information that will aid in satisfying 1) design and regulation requirements, 2) barrier performance assessment requirements, and 3) hydrologic and other barrier task input needs. The strategy applied to accomplish this is a series of task studies that provide for an understanding of the range and probability for recurrence of past climate change and for a projection of potential future climate at the Hanford Site. These tasks focus on identifying and characterizing historic and prehistoric climatic patterns through literature review and specialized field studies. A local climate forecast model is being developed that will couple the past climate patterns with models of regional and global climate change to provide test scenarios that can be used in barrier performance assessment. The ultimate object of these efforts is to obtain defensible probabilistic projections of the long-term climate variability in Hanford Site and Pasco Basin region.

Late in FY 1989 an independent third-party technical peer panel reviewed a draft study plan for the climate change task. That draft study plan reflected an integration of plans first developed for the Basalt Waste Isolation Project (BWIP) with the needs of the Protective Barrier Development Program. In FY 1990, the study plan was completed. The study plan contains task and subtask descriptions, preliminary budget estimates, and schedules. Based largely on the recommendations of the third-party review, the program has become more focused, and the cost of periorming the work has been reduced from an initial estimate based on applicable BWIP costs in FY 1988 of $\$ 3.4$ million to a current estimate of about $\$ 1.9$ million contained in the current study plan. This amount could be reduced even more depending on the outcome of criticaldecision points in the work strategy.
The tasks and subtasks in the climate program have been numbered as follows:

0. Task Administration

1. Identification of Climatic Data Needs

2. Synthesis of Existing Information

2.1 Modern Climatic Patterns

2.2 Holocene Paleoclimate Literature

2.3 Late Quaternary Literature

2.4 Flood Records

2.5 Global Climate Modeling

3. Pollen and Lake Sediment Studies

3.1 Scablands Pollen Site Transect

3.2 Full Glacial Pollen Study

4. Fluvial Sediments and Ground Water Studies

4.1 Fluvial Indicators

4.2 Episodic Ground Water Recharge

5. Terrestrial Sediment Studies

5.1 Studies of Eolian Processes

5.2 Faunal Indicators

6. Past Climate/Vegetation Variations

7. Future Climate/Vegetation Projections

8. Local Climate Forecast Model

9. Model Calibration and Validation

10. Projection of Future Climates

11. Generation of Weather Statistics

12. Identification of Future Spatial Analogs

13. Input to Barrier Performance Assessment

Notable highlights for FY 1990 include the completion of an article entitled Paleoecology and Paleoclimates of the Columbia Basin Region by J. C. Chatters to be submitted to a professional journal. This effort supports Task 2 (Synthesis of Existing Information), Subtask 2.1 (Holocene Paleoclimate Literature). In the article, the author summarizes and synthesizes existing proxy evidence for climatic and ecological change in the Columbia Basin of northwestem America since $10 \mathrm{ka}$ to $13 \mathrm{ka}$ (thousands of years ago). Inferences based on glacial and fluvial geomorphology, cave and lacustrine sedimentation patterns, palynology, fossil 
timberlines, subfossil paleontology, and stable isotope study of inland lakes are integrated into a detailed record of environmental change. Findings identify a terminal Pleistocene environment kept cool and dry by masses of ice and glacial meltwater, supporting a mosaic of now-allopatric plant and animal communities. This was followed between $10 \mathrm{ka}$ and $8.5 \mathrm{ka}$ by a period of warmer-than-modem summers, colder-than-modem winters and low, but spring-dominant precipitation, supporting extensive grasslands and the faunas associated with them. By 8 ka summer and winter were both relatively warm, and precipitation was at least $33 \%$ below modem levels. This climate pattern resulted in reduced stream flows with late spring flow maxima and extensive development of shrub-steppe vegetation throughout most of the region. Climate cooled but remained dry between $5.4 \mathrm{ka}$ and $4.5 \mathrm{ka}$, then underwent a period of transition to wetter, cooler conditions between $4.5 \mathrm{ka}$ and $3.9 \mathrm{ka}$. Rivers flooded frequently, and forests expanded into steppe zories. From 3.9 ka until $2.4 \mathrm{ka}$ the climate was cool in summer and cold in winter, with winter-dominant precipitation at least $30 \%$ above modem amounts. Alpine glaciers underwent the first synchronous advance of the Holocene. Rivers stabilized, and their peak flows were delayed into midsummer; steppe vegetation increased in density as subalpine and probably montane forests expanded beyond their modern margins. Warmer, drier conditions returned between $2.4 \mathrm{ka}$ and $2 \mathrm{ka}$, reducing vegetation density and bringing a renewal of severe flooding. Climate then improved somewhat, and modem climates were established. The Little Ice Age, although evident in alpine cirques, had little apparent effect on regional environments except for a slight drying around $\mathbf{5 5 0}$ years ago. Figure 2.27 compares modern and reconstruction vegetation for various time periods.

Under Task 3 (Pollen and Lake Sediments Studies), subcontracts were put in place with Washington State University, Pullman, and Golder Associates, Seattle, to collect, date, and analyze fossil pollen and other lake sediment data obtained from long sediment cores to allow further refinement of the developing climate history of the Pasco Basin region highlighted above and provide more location-specific climatic information with special emphasis on the periods $125 \mathrm{ka}, 18 \mathrm{ka}$, $9 \mathrm{ka}, 6 \mathrm{ka}$, and $3.5 \mathrm{ka}$. The task has been divided into two subtasks.

Subtask 3.1 is a transect of pollen sites across the scablands of the central Columbia Basin. In FY 1990, the subtask focused on the pollen records contained in the lacustrine sediments from three lakes, Williams (near Cheney, Washington), Wildcat (near Hooper, Washington), and Sulphur (near Connell, Washington) that extend from the present forest zone into the steppe, zone of eastern Washington (Figure 2.27). This was expected to provide detailed information on the distributions of vegetation types and levels of ground water in the Pasco Basin and vicinity. The pollen analysis completed in FY 1990 for the $13-k$ year record from Wildcat Lake shows that climatic changes associated with the end of the last glaciation were consistently at least as rapid, if not more rapid, than those predicted to result from the buildup of greenhouse gases. The 13-k year record from Williams Lake exhibits a similar transition, but in more detail and extended over a longer period. Efforts to core Sulphur Lake below Mazama volcanic ash (which dates approximately $6.8 \mathrm{ka}$ ) in FY 1990 were unsuccessful. The sediments post-dating the Mazama ash layer had a banded character that may have resulted from rapidly fluctuating water levels that may prove to be an especially good indicator of ground-water levels in the area just east of the Hanford Site.

Subtask 3.2 (Full Glacial Pollen Study) was directed at coring Carp Lake, near Goldendale, southeast of the Hanford Site. This site completes the northeast to southwest transect of pollen that cuts through the Pasco Basin (Figure 2.27). A geophysical survey of the bottom of Cam Lake was performed to locate the deepest sediment section of the lake, but the effort was not completely successful. The lake coring operation has been successful in recovering over $19.3 \mathrm{~m}$ of lake sediment. The age of a $15-\mathrm{cm}$ volcanic ash layer at $8 \mathrm{~m}$ depth is known to be $33 \mathrm{ka}$ based on the earlier coring efforts at the lake. This gives a deposition rate of approximately $4.0 \mathrm{k}$ years per meter and suggests that the age of the recovered sediments may be as old as $75 \mathrm{k}$ years at $18 \mathrm{~m}$ and because of compaction could possibly be as old as $125 \mathrm{k}$ years. A number of volcanic ash layers occur in the recovered sediment core.

Another subcontract to Washington State University supports Task 5 (Terrestrial Sediment Studies), Subtask 5.1 (Studies of Eolian Processes). This subtask studied the relationship between eolian processes and climatic conditions during the postglacial period (last $10 \mathrm{ka}$ to $13 \mathrm{ka}$ ) on and around the Hanford Site.

The FY 1990 research involved 1) assessing aerial photography and location of appropriate eolian sample locales; 2) performing trench studies and sampling eolian deposits; 3 ) conducting reconnaissance studies 

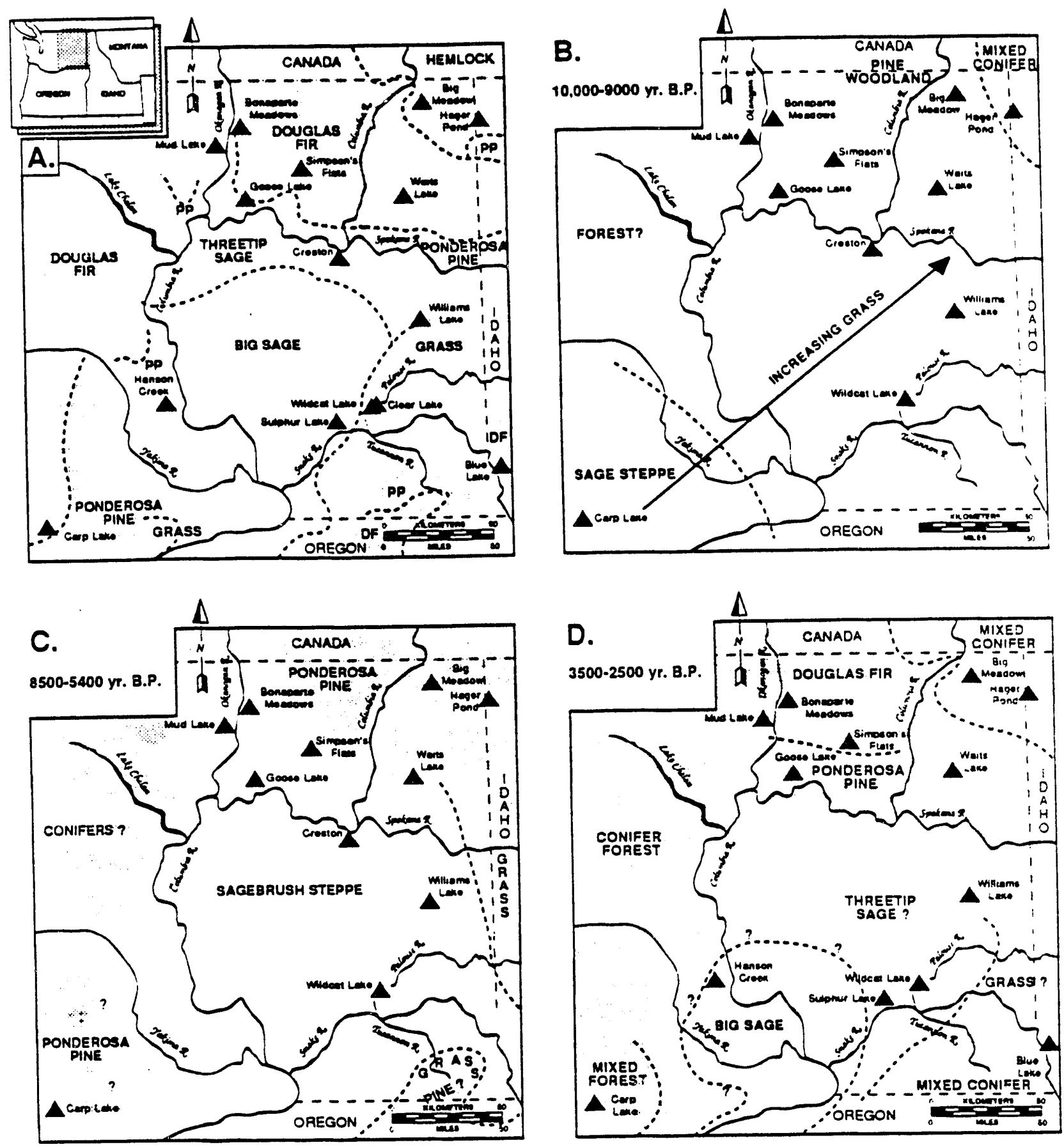

Figure 2.27. Modern Distribution of Vegetation Zones in the Columbia Basin ( $A$, upper left) Compared with Reconstructions of Vegetation Patterns for Three Periods During the Holocene (B, C, D). Modern vegetation patterns are from Daubenmire (1970) and Franklin and Dyrness (1973). 
for dune deposits containing datable volcanic ash and archaeological sites; 4 ) analyzing texture and composition of eolian samples; and 5) locating, describing, and sampling Holocene-aged alluvial and alluviaVeolian sediments in the Dry Creek Canyon, along the "horn" of the Yakima River and on the northeastern flanks of Rattlesnake Mountain.

Initial findings indicated first that individual active dunes in the limited area of study have both increased and decreased in size and area during the last $\mathbf{4 0}$ years. Second, in general, there has been an apparent trend toward increased stability [decrease in (approximately 40-year)] dune migration rates range from approximately 2 to $4 \mathrm{~m} / \mathrm{yr}$, but relationships are complex. Third, rapid restabilization of the previously stabilized dune surface following a 1984 wildfire suggested that the climatic threshold needed to promote wholesale site-wide sand dune reactivation was not breached for long. Fourth, textural analyses of samples from southern portions of the site showed a crude, fining downwind trend from southwest to northeast across the Hanford Site. Concentrations of coarse-grained sediment (mean grain sizes from medium- to coursegrained sand) occurred on and adjacent to the 200 Areas and near the easternmost flanks of Rattlesnake Mountain. Concentrations of fine-grained sediment (mean grain sizes from fine- to medium-grained sand) occurred between the old Hanford townsite and the Washington Public Power Supply System reactors. Finally, two radiocarbon samples from the Dry Creek locality were analyzed and returned dates of $9.3 \mathrm{ka}$ from the base of the sequence and $6.4 \mathrm{ka}$ within $3 \mathrm{~m}$ of the surface. These results indicate that fluvial deposition was rapid during the early Holocene, but has slowed substantially since $6.4 \mathrm{ka}$. 


\subsection{REFERENCES}

Adams, M.R., and N.R. Wing. 1986. Protective Barrier and Warning Marker System Development Plan. RHO-RE-OL-35P, Rockwell Hantord Operations, Richland, Washington.

Campbell, M.D., G.W. Gee. 1990. Field Lysimeter Test Facility: Protectlve Barrler Test Results (FY 1989, The Third Year). PNL-7558, Pacific Northwest Laboratory, Richland, Washington.

Campbell, M.D., G.W. Gee, M.J. Kanyid, and M.L. Rockhold. 1990. Field Lysimeter Test Facillty: Second Year (FY 1989) Test Results. PNL-7209, Pacific Northwest Laboratory, Richland, Washington.

Daubenmire, R. 1970. Steppe Vegetation of Washington, Washington Agricultural Experiment Station, Technical Bulletin 62, Pullman, Washington.

Fayer, M.J. 1990. Test Plan for Hydrologic Modeling of Protective Barriers. PNL-7152, Pacific Northwest Laboratory, Richland, Washington.

Franklin, J.F., and J.T. Dymess. 1973. Natural Vegetation of Oregon and Washington, General Technical Report PNW-8, U.S. Department of
Agriculture, Forest Service, Pacific Northwest Forest and Range Experiment Station, Porland, Oregon.

Glantz, C.S., M.N. Schwartz, K.W. Burk, R.B. Kaspar, M.W. Ligotke, and D.J. Perrault. 1990. Climatological Summary of Wind and Temperature Data for the Hanford Meteorology MonitorIng Network. PNL-7471, Pacific Northwest Laboratory, Richland, Washington.

Gee, G.W., R.R. Kirkham, J.L. Downs, and M.D. Campbell. 1989. The Field Lysimeter Test Facility (FLTF) at the Hanford Site: Installation and Initial Tests. PNL-6810, Pacific Northwest Laboratory, Richland, Washington.

Hunter, C.R., A.J. Busacca, and W.J. Waugh. 1990 A Feasibility Study of Modeling Pedogenic Carbonates in Solls and Sediments at the U.S. Department of Energy's Hanford Site. PNL-7413, Pacific Northwest Laboratory, Richland. Washington.

Kirkham, R.R., G.W. Gee, and J.L. Downs. 1987. An Experimental Plan for the Field Lysimeter Test Facility (FLTF). PNL-6351, Pacific Northwest Laboratory, Richland, Washington. 


\subsection{PROTECTIVE BARRIER DOCUMENTS (Published to date)}

Phillips, S.J., M.R. Adams, T.W. Gilbert, C. C. Meinhardt, R.M. Mitchell, and W.J. Waugh. 1985. Engineered Barrier Test Facility Status Report: 1984. RHOWM-SR-3P, Rockwell Hanford Operations, Richland, Washington.

Fayer, M.J., W. Conbere, P.R. Heller, and G.W. Gee. 1985. Modiel Assessment of Protective Barrier Designs. PNL-5604, Pacific Northwest Laboratory, Richland, Washington.

Myers, D.R. 1985. Disposal Materials Study. RHOWP-EV-12P, Rockwell Hanford Operations, Richland, Washington.

Adams, M.R., and M.F. Kaplan. 1986. "Marker Development for Hanford Waste Site Disposal". In R.G. Post (ed.) Waste Management '86, (Vol. 1), pp. 425-431, University of Arizona, College of Engineering and Mines, Tucson, Arizona.

Phillips, S.J., and J.N. Hartley. 1986. "Protective Barrier Systems for Final Disposal of Hanford Waste Sites." In R. G. Post (ed.) Waste Management '86, (Vol. 1), pp. 433-437, University of Arizona, College of Engineering and Mines, Tucson, Arizona.

Kaplan, M.F., and M.R. Adams. 1986. "Using the Past to Protect the Future: Marking Nuclear Waste Disposal Sites." Archeology 39(5): 51-54.

Adams, M.R. and N.R. Wing. 1986. Protectlve Barrler and Warning Marker System Development Plan. RHO-RE-OL-35P, Fockwell Hanford Operations, Richland, Washington.

Fayer, M.J. 1987. Model Assessment of Protective Barrler Designs: Part II. PNL-6297, Pacific Northwest Laboratory, Richland, Washington.

Last, G.V., M.A. Glennon, M.A. Young, and G.W. Gee. 1987. Protectlve Barrier Materlals Analysis: Fine Soll Site Characterization. PNL-6314, Pacific Northwest Laboratory, Richland, Washington.

Gee, G.W. 1987. "Preliminary Analysis of the Performance of the Protective Barrier and Marker System."
Appendix $M$ in Final Environmental Impact Statement, Disposal of Hanford Defense High-Level, Transuranic and Tank Wastes, DOE/EIS-0113, U.S. Department of Energy - Richland, Operations Office, Richland, Washington.

Kirkham, R.R., G.W. Gee, and J.L. Downs. 1987. Field Lysimeter Test Facility for Protective Barriors: Experimental Plan. PNL-6351, Pacific Northwest Laboratory, Richland, Washington.

Waugh, W.J., and S.O. Link. 1988. Barrier Erosion Control Test Plan: Gravel Mulch, Vegetation, and Soll Water Interactions. WHC-EP-0067, Westinghouse Hanford Company, Richland, Washington.

Wing, N.R., M.D. Campbell, J.L. Downs, G.W. Gee, R.R. Kirkham, and S.J. Phillips. 1988. "Protective Barrier Development: The Field Lysimeter Test Facility". In Proceedings of the International Topical Meeting on Nuclear and Hazardous Waste Management Spectrum '88. pp. 196-198. American Nuclear Society, Inc., La Grange Park, Illinois. WHC-SA-0203FP, Westinghouse Hanford Company, Richland, Washington.

Phillips, S.J., M.S. Ruben, and R.R. Kirkham. 1988. "Engineered Surface Barriers for Waste Disposal Sites: Lysimeter Facility Design and Construction". In DOE Model Conference Proceedings, pp. 1229-1238. CONF-881054. Oct. 3-7, Martin Marietta, Oak Ridge, Tennessee.

Ligotke, M.W. 1988. Soll Erosion Rates from Mixed Soll and Gravel Surfaces in a Wind Tunnel: A Preliminary Report. PNL-6677, Pacific Northwest Laboratory, Richland, Washington.

Waugh, W.J., and M.G. Foley. 1988. Protective Barrier Climate-Change Impacts: Technical Workshop Findings and Recommendations. PNL-6615, Pacific Northwest Laboratory, Richland, Washington.

Ligotke, M. W. 1989. Surface Stability Test Plan for Protective Barriers. PNL-6722, Pacific Northwest Laboratory, Richland, Washington. 
Gee, G.W., R.R. Kirkham, J.L. Downs, and M.D. Campbell. 1989. The Fleld Lysimeter Test Facillty (FLTF) at the Hanford Site: Installation and initial Tests. PNL-6810, Pacific Northwest Laboratory, Richland, Washington.

Gee, G.W., M.D. Campbell, H.D. Freeman, and J.F. Cline. 1989. Assessment of Cover Systems at the Grand Junction, Colorado Uranium Mill Tallings Plle: 1987 Field Measurements. PNL-6762, Pacific Northwest Laboratory, Richland, Washington.

Cadwell, L.L., E.L. Eberhardt, and M.A. Simmons. 1989. Animal Intrusion Studles for Protective Barriers: Status Report for FY 1988. PNL-6869, Pacific Northwest Laboratory, Richland, Washington.

Freeman, H.D., G.W. Gee, and J.F. Relyea. 1989. Field Study Plan for Alternate Barriers. PNL-6840, Pacific Northwest Laboratory, Richland, Washington.

Freeman, H.D., and G.W. Gee. 1989. Hanford Protective Barriers Program Asphalt Barrier Studies - FY 1988. PNL-6874, Pacific Northwest Laboratory, Richland, Washington.

Waugh, W.J. 1989. Gravel Admix, Vegetation and Soll Water Interactions in Protective Barriers: Experimental Design, Construction and Initlal Condltions. PNL-6616, Pacific Northwest Laboratory, Richland, Washington.

Freeman, H.D., and G.W. Gee. 1989. Hanford Protectlve Barriers Program: Status of Asphalt Barrler Study - FY 1989. PNL-7513, Pacific Northwest Laboratory, Richland, Washington.

Link, S.O., and W.J. Waugh. 1989. Evapotransplration Studles for Protectivs Barriers: Experimental Plans. PNL-6899, Pacific Northwest Labcratory, Richland, Washington.

Wing, N.R. and G.W. Gee. 1989. Protectlve Barrler Development. Presented at the "Environmental Hazards Conference and Exposition," Bellevue, Washington, February 14-16, 1989, WHC-SA-0480VA, Westinghouse Hanford Company, Richland, Washington.

Petersen, K.L. 1990. "The Long-Term Climate Change Assessment Task of the Protective Barrier Development Program for Low-Level Waste Site Remediation at the Hanford Site, Washington". In High Level Radloactlve Waste Management. Vol 2, pp. 12351239. Proceeding of an International Topical Meeting. American Nuclear Society, La Grange, Park, Illinois. WHC-SA-00808-FP, Westinghouse Hanford Company, Richland, Washington.

Fayer, M.J. 1990. Test Plan for Hydrologic Modeling of Protectlve Barriers. PNL-7152, Pacific Northwest Laboratory, Richland, Washington.

Wing, N.R., and G.W. Gee (eds). 1990. Hanford Site Protective Barrier Development Program: Fiscal Year 1989 Highlights. WHC-EP-0318, Westinghouse Hanford Company, Richland, Washington.

Campbell, M.D., G.W. Gee, M.J. Kanyid, and M.L. Rockhold. 1990. Field Lysimeter Test Facility: Second Year (FY 1989) Test Results. PNL-7209, Pacific Northwest Laboratory, Richland, Washington.

Landeen, D.S., L.L. Cadwell, L.E. Eberhardt, R.E. Fitzner, and M.A. Simmons. 1990. Animal Intrusion Fleld Test Plan. WHC-EP-0253. Westinghouse Hanford Company, Richland, Washington.

Petersen, K.L. 1990. The Long-Term Climate Change Assessment Task of the Protective Barrier Development Program for Low-Level Waste Site Remedlation at the Hanford SIte, Washington. WHCSA-00808-FP, Westinghouse Hanford Company, Richland, Washington.

Link, S.O., M.E. Thiede, R.D. Evans, J.L. Downs, and W.J. Waugh. 1990. Evapotranspiration Studies for Protectlve Barriers: FY 1988 Status Report. PNL6985, Pacific Northwest Laboratory, Richland, Washington.

Walters, W.H., K.A. Hoover, and L.L. Cadwell. 1990. Project Test Plan for Runoff and Erosion on FineSoll Barrier Surfaces and Rock-Covered SIde Slopes. PNL-6791, Pacific Northwest Laboratory, Richland, Washington.

Hoover, K.A., L.L. Cadwell, and W.H. Walters. 1990. Hanford Protective Barriers Program: Water Erosion Studles - FY 1989. PNL-7214, Pacific Northwest Laboratory, Richland, Washington. 
Landeen, D.S. 1990. Animal Intrusion Status Report for Fiscal Year 1989. WHC-EP-0299, Westinghouse Hanford Company, Richland, Washington.

Ligotke, M.W., and D.C. Klopier. 1990. Soll Erosion Rates from Mixed Soil and Gravel Surfaces in a WInd Tunnel. PNL-7435, Pacific Northwest Laboratory, Richland, Washington.

Waugh, W.J., M.E. Thiede, C. J.Kemp, L. L.Cadwell, and S. O.Link. 1990. Field Study of Gravel Admix, Vegetation, and Soll Water Interactions: Protective Barrier Program Status Report - FY 1989. PNL7440, Pacific Northwest Laboratory, Richland, Washington.

Hunter, C.R., A.J. Busacca, and W.J. Waugh. 1990. A Feasibility Study of Modeling Pedogenic Carbonates in Solls and Sediments at the U.S. Department of Energy's Hanford Site. PNL-7413, Pacific Northwest Laboratory, Richland, Washington.

Wing, N.R. and G.W. Gee. 1990. "Protective Barrier Development: Overview". In Proceedings of the Twenty-Eighth Hanford Symposium on Health and the Environment, Environmental Monitoring, Restoration, and Assessment: What Have We Learned?, pp. 147-151, R. H. Gray (Editor), Pacific Northwest Laboratory, Richland, Washington.

Wing, N.R. and G.W. Gee. 1990. "Protective Barrier Development: Overview". In Proceedings of the
International Topical Meeting on Nuclear and Hazardous Waste Management Spectrum '90. pp. 335 337. American Nuclear Society, Inc., La Grange Park, Illinois. Westinghouse Hanford Company, Richland, Washington.

Glantz, C.S., M.N. Schwartz, K.W. Burk, R.B. Kaspar, M.W. Ligotke, and D.J. Perrault. 1990. Climatological Summary of Wind and Temperature Data for the Hanford Meteorology Monitoring Network. PNL7471, Pacific Northwest Laboratory, Richland, Washington.

Sackschewsky, M.R., J.C. Chatters, S.O. Link, and C.A. Brandt. 1991. Protective Barrler Program: Test Plan for Plant Community Dynamics. WHC. EP-0380. Westinghouse Hanford Company, Richland, Washington.

Nichols, W.E. 1991. Comparative Simulations of a Two-Layer Landfill Barrier Using the Help Version 2.0 and UNSAT-H Version 2.0 Computer Codes. PNL-7583, Pacific Northwest Laboratory, Richland. Washington

Landeen, D.S. 1991. Animal Intrusion Status Report for Fiscal Year 1990. WHC-EP-0398. Westinghouse Hanford Company, Richland. Washington. 


\section{APPENDIX A}

Protective Barrier Development Teams 


\section{APPENDIX A}

\section{Protective Barrier Development Teams}

Barrier Design Team (BDT)

N. Richard Wing (WHC, Task Leader)

Jerry W. Cammann (WHC)

Sheryl D. Consort (KEH)

David L. Fort (KEH)

Glendon W. Gee (PNL)

Dennis R. Myers (WHC)

Steven J. Phillips (WHC)

Barrier Technical Advisory Board (BTAB)

Project Management

Biointrusion Control

Water Infilitation Control

Erosion/Deposition Control

Physical Stability Testing

Human Interference Control

Barrier Construction Materials

Prototype Barrier Designs and Testing

Model Applications and Validation

Natural Analog Studies

Long-term Climate Change Effects

Quality Assurance

Final Design
Jerry W. Cammann (WHC)

Larry L. Cadwell (PNL)

Glendon W. Gee (PNL)

Wallace H. Walters, Jr. (PNL)

Steven J. Phillips (WHC)

Kenneth I . Petersen (WHC)

Dennis R. Myers (WHC)

N. Richard Wing (WHC)

Michael J. Fayer (PNL)

James C. Chatters (PNL)

Kenneth L. Petersen (WHC)

John J. Verderber (WHC)

Barrier Design Team 


\section{DISTRIBUTION}

No. of

Copies

\section{OFFSITE}

12

DOE/Office of Scientific and

Technical Information

4 Jacobs Engineering Group, Inc. 5301 Central Avenue NE Suite 1700

Albuquerque, NM 87108

ATTN: M. Kyllo

N. B. Larson

F. Titus

T. Goering

4

Los Alamos National Laboratory

P. O. Box 1663

Los Alamos, NM 87545

ATTN: T. E. Hakonson

J. W. Nyham

F. Barnes

T. D. Oakley

2

U.S. Ecology

P. O. Box 7246

9200 Shelbyville Rd

Suite 526

Louisville, KY 40207

ATTN: R. E. Sauer

D. Lane

2 U.S. Nuclear Regulatory Commission Division of Engineering Safety

MS NL-005

Washington, DC 20555

ATTN: E. O'Donnell

T. J. Nicholson

$6 \quad$ U.S. Department of Energy

Office of Environmental Restoration

and Waste Management

1000 Independence Ave. S. W.

Washington, DC 20585

ATTN: L. P. Duffy, EM-1

C. Frank, EM-50

D. C. Fulmer, EM-43

J. E. Lytle, EM-30

S. A. Mann, EM-44

R. P. Whittield, EM-40
No. of

Copies

3 U.S. Department of Energy

Office of Civilian Radioactive Waste Management

ATTN: L. H. Barrett, R-20

D. E. Shelor, RW-3

R. Stein, RW-30

W. Brewer

Office of High-Level Nuclear

Waste Management

Washington State Department of Ecology

Olympia, WA 98504

2 Agronomy Department

Washington State University

Pullman, WA 99164

ATTN: A. J. Busacca

G. S. Campbell

E. M. Carlin Low-Level Radioactive Waste Program Washington Department of Ecology

Mail Stop PV-11

Olympia, WA 98504

4 Chem Nuclear Geotech

P.O. Box 14000

Grand Junction, CO 81502

ATTN: Jack Duray John Elmer

Vince Ponc

W. J. Waugh

2 U. S. Department of Energy

785 DOE Place

Idaho Falls, ID 83402

ATTN: O. D. Markham

T. E. Reynolds

2 EG\&G Idaho, Inc.

P. O. Box 1625

Idaho Falls, ID. 83415-3900

ATTN: J. E. Conner

K. M. Kostelnik 
C. Massimino

U. S. Environmental Protection Agency

1200 Sixth Avenue

Seattle, WA 98101

Peter J. Mehringer

Anthropology Department

Washington State University

Pullman, WA 99164

Jerry Olson

U.S. Bureau of Mines

Spokane Research Center

East Montgomery

Spokane, WA 99207

\section{Alan Rainey}

Department of Health

Radiation Protection Division

Airdustrial Park

BIdg. 5, M.S. LE-13

Olympia, WA 98504

\section{J. Rensel}

High-Level Waste Management

Washington State Department of Ecology

Mail Stop Pu II

Olympia, WA 98504

R. K. Schulz

University of California

Department of Plant and Soil Biology

Berkeley, CA 94720

W. J. Brumley

U.S. Department of Energy

Savannah River Operations Office

P.O. Box A

Aiken, SC 29801

F. T. Fong

U.S. Department of Energy

San Francisco Operations Office

1333 Broadway

Oakland, CA 94612
M. R. Jugan

U.S. Department of Energy

Oak Ridge Operations Office

P.O. Box E

Oak Ridge, TN 37830

E. Maestas

U.S. Department of Energy

West Valley Project Office

P.O. Box 191

West Valley, NY 14171

\section{Matthews}

U.S. Department of Energy

Albuquerque Operations Office

P.O. Box 5400

Albuquerque, NM 87185

C. S. Abrams

Argonne National Laboratory

P.O. Box 2528

Idaho Falls, ID 83401

3 Battelle Memorial Institute

Project Management Division

505 King Avenue

Columbus, OH 43201

ATTN: W. A. Carbeiner

W. S. Madia

Technical Library

P. J. Wierenga

Department of Soil and Water Science 429 Shantz Building

University of Arizona

Tucson, AZ 85721

J. R. Berreth

Westinghouse Idaho Nuclear Co.

P.O. Box 4000

Idaho Falls, ID 83401

A. T. Clark

Division of Fuel Material Safety

U.S. Nuclear Regulatory Commission

Washington, D.C. 20555 
No. of

Copies

G. A. Dinwiddie

U.S. Geological Survey

12201 Sunrise Valley Drive

Reston, VA 22092

6 Westinghouse Savannah River

Company

Aiken, SC 29801

ATTN: R. G. Baxter

M. D. Boersma

J. G. Glasscock

J. R. Knight

M. J. Plodinec

C.T. Randall

3 Low-Level Radioactive Waste Program

U.S. Geological Survey

Water Resources Division

12201 Sunrise Valley Drive

Reston, VA 22092

ATTN: J. Fisher

P. Stevens

N. Trask

L. Frank

U.S. Department of Energy

625 Marion Street, N.E.

Salem, OR 97310

P. G. Hagan

Joint Integration Office

Carlmont Executive 1

4308 Cartisle, N.E.

Albuquerque, NM 87101

D. Hillel

Department of Plant and Soil Science

12A Stockbridge Hall

University of Massachusetts

Amherst, MA 01003

W. A. Jury

Department of Soils

University of California

at Riverside

Riverside, CA 92502
No. of

Copies

D. A. Knecht

Westinghouse Idaho Nuclear Co.

P.O. Box 4000

Idaho Falls, ID 83403

S. Meyers

U.S. Environmental Protection Agency

Office of Radiation Programs

(ANR-458)

401 M Sireet, S.W.

Washington, D.C. 20460

4

Oak Ridge National Laboratory

P.O. Box Y

Oak Ridge, TN 37830

ATTN: J. O. Blomeke

W. D. Burch

R. T. Jubin

L. J. Mezga

L. D. Ramspott

Lawrence Livermore National Laboratory

University of California

P.O. Box 808

Livermore, CA 94550

E. M. Romney

Laboratory of Biomedical and

Environmental Sciences

University of California at Los Angeles

Los Angeles, CA 90024

S. W. Childs

Cascade Earth Sciences, Ltd.

P.O. Box 137

Corbett, OR 97019

2

Sandia National Laboratories

P.O. Box 5800

Albuquerque, NM 87185

ATTN: R. W. Lunch

Technical Library

R. Shaw

Electric Power Research Institute

3412 Hillview Avenue

Palo Alto, CA 94304 
M. J. Steindler

Argonne National Laboratory

9700 South Cass Avenue

Argonne, IL 60439

2 Desert Research Institute

P.O. Box 60220

Reno, NV 89506

ATTN: J. T. Ball

S. Tyler

\section{E. P. Weeks}

U.S. Geological Survey

Federal Center Mail Stop 413

Denver, CO 80225

4 Idaho National Engineering Laboratory

P.O. Box 1625

Idaho Falls, ID 83415

ATTN: M. A. Knecht

J. B. Sisson

B. B. Russell

Technical Library

N. Ingraham

Desert Research Institute

Suite 1

2505 Chandler Avenue

Las Vegas, NV 89120

R. G. Hills

Department of Mechanical Engineering

New Mexico State University

Box 30001

La Cruces, NM 88003

2 New Mexico State University

Agricultural Experiment Station

Box 3BF

Las Cruces, NM 88003

ATTN: T. L. Jones

D. M. Briggs

\section{W. Wright}

Colorado Department of Health

Drinking Water Division

4210 E. 11 th Avenue

Denver, CO 80220
I. Winograd

U.S. Geological S'ınvey

MS 432

Reston, VA 22092

R. Treat

EBASCO

Richland, WA 99352

M. Silberberg

Waste Management Branch

Office of Nuclear Regulatory Research

U.S. Nuclear Regulatory Commission

Washington, DC 20555

R. C. Letcher

U.S. Department of Energy

Morgantown Energy Technology Center

P.O. Box 880

Morgantown, WV 26505

C. R. McKee

In-Situ, Inc.

P.O. Box 1

Laramie, WY 82070

J. W. Mercer

GeoTrans, Inc.

250 Exchange Place

Suite A

Herndon, VA 22070

A. A. Eiseewi

Southern California Edison

P.O. Box 800

Rosemead, CA 91770

2 Geology Department

Washington State University

Pullman, WA 99164

ATTN: K. Keller

D. Gaylord

L. J. Fritschen

Forestry Department

University of Washington

Seattle, WA 98195 
$4 \quad$ West Valley Nuclear Service Company

P.O. Box 191

West Valley, NY 14171

ATTN: R. R. Borisch

$$
\begin{aligned}
& \text { J. Buggy } \\
& \text { J. M. Pope } \\
& \text { R. A. Thomas }
\end{aligned}
$$

\section{EOREIGN}

P. Grimwood

Waste Management Unit

British Nuclear Fuels plc

Sellafield

Seascale, Cumbria CA201PG

ENGLAND

Graham M. Smith

Environmental Sciences Group Intera-Exploration Consultants Ltd.

Highlands Farm, Greys Road

Henley-on-Thames

Oxon RG94PS

ENGLAND

\section{ONSITE}

9 DOE Field Office. Richland

G. J. Braken

J. J. Broderick

R. D. Freeburg

M. J. Furman

R. E. Gerton

J. D. Goodenough

J. M. Hennig

R. D. Izatt

J. P. Sands

1 EPA - Hanford Project Office

D. R. Sherwood, A7-70

47 Westinghouse Hanferd Company

M. R. Adams

H. Babad

J. D. Berger

R. J. Bliss

L. C. Brown

J. W. Cammann

R. A. Carlson

J. D. Davis

C. J. Geier

R. L. Gilchrist

W. F. Heine

J. M. Henderson

G. W. Jackson

K. N. Jordan

C. J. Kemp

D. S. Landeen

R. E. Lerch

H. E. McGuire

D. R. Myers

D. J. Newland

B. E. Opitz

K. L. Petersen

S. J. Phillips

R. C. Roos

M. R. Sackschewsky

J. L. Scott

J. C. Sonnichsen

D. R. Speer

J. A. Voogd

S. A. Weigman

G. W. Williamson

N. R. Wing (15)

D. D. Wodrich

R. D. Wojtasek

J. C. Womack

D. E. Wood

Pacific Northwest Laboratory

L. L. Cadwell

M. D. Campbell

J. C. Chatters

J. L. Downs

L. E. Eberhardt

J. W. Falco

M. J. Fayer

M. G. Foley

H. D. Freeman

G. W. Gee (20)

J. M. Hales

P. C. Hays

C. T. Kincaid

R. R. Kirkham

G. V. Last

M. W. Ligotke

S. O. Link 
No. of

Copies

Pacific Northwest Laboratory (contd)
M. L. Rockhold
L. E. Rogers
M. A. Simmons
R. L. Skaggs
S. C. Slate
D. L. Stewart
T. L. Stewart

No. of

Copies
J. A. Stottlemyre
G. P. Streile
M. E. Thiede
J. M. Thomas
W. H. Walters
R. E. Wildung
Publishing Coordination
Technical Report Files (5) 

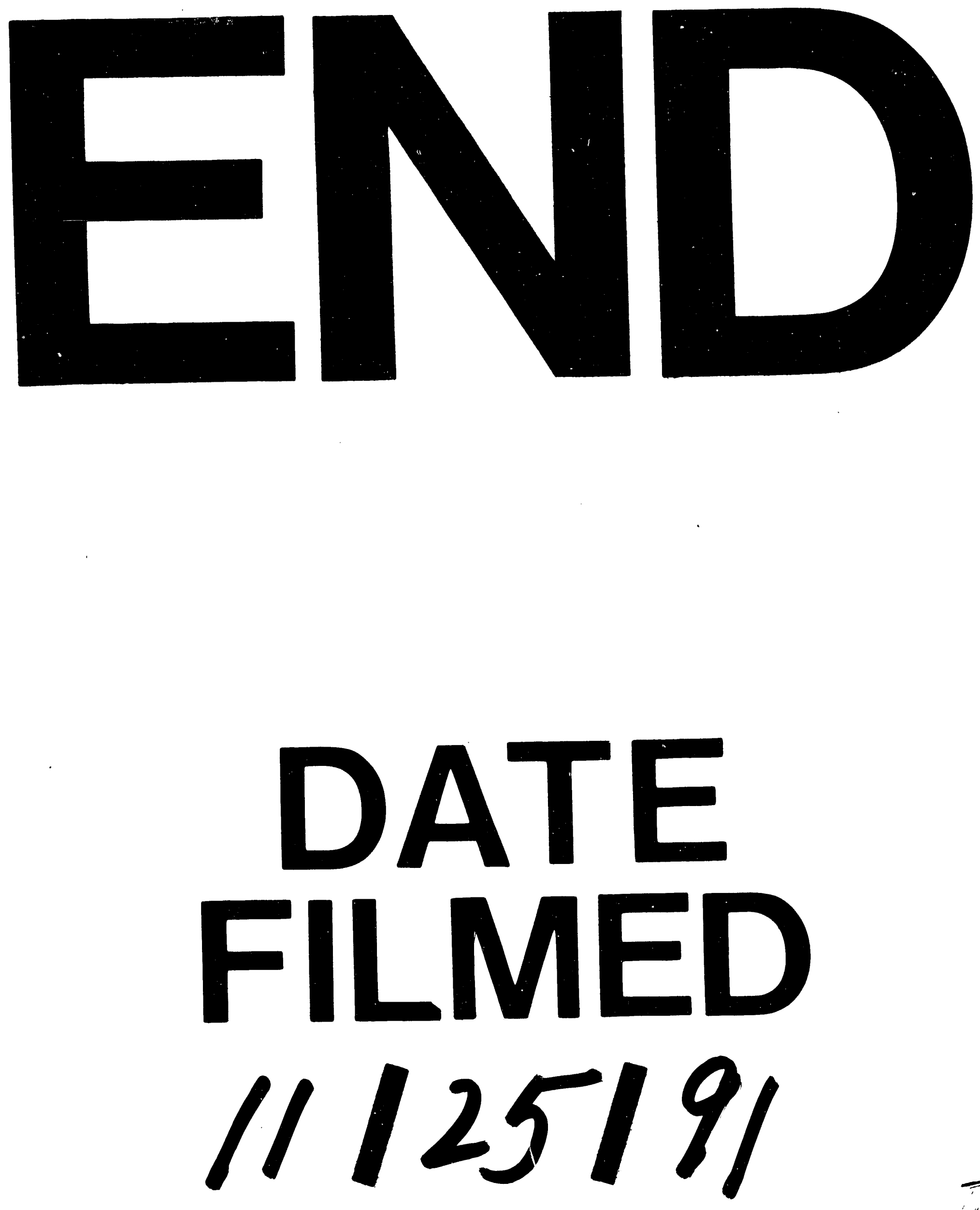
